\title{
Social-ecological challenges in the Yellow River basin (China): a review
}

\author{
Christian Wohlfart $^{1} \cdot$ Claudia Kuenzer $^{2} \cdot$ Cui Chen $^{3,4} \cdot$ Gaohuan Liu $^{5}$
}

Received: 26 February 2016/Accepted: 28 June 2016/Published online: 7 July 2016

(C) Springer-Verlag Berlin Heidelberg 2016

\begin{abstract}
The human-environment relationship within the Yellow River basin has a long history, because favorable environmental circumstances allowed the early emergence of societies along the river banks, and hence, the Yellow River basin was the birthplace of ancient Chinese civilization. On the other hand, the Yellow River is "China's sorrow" due to the constant occurrences of flooding events throughout history. In recent decades, the Yellow River basin is facing a spectacular economic boom, but mainly achieved at the expenses of the environment by over-exploiting the natural resources provided within the basin, which causes various challenges on ecology and society. Water scarcity, pollution, and ecosystem degradation accompanied with biodiversity decline have been further
\end{abstract}

This article is part of a Topical Collection in Environmental Earth Sciences on "Environment and Health in China II," guest edited by Tian-Xiang Yue, Cui Chen, Bing Xu, and Olaf Kolditz.

Christian Wohlfart

christian.wohlfart@ remote-sensing-biodiversity.org

1 Company for Remote Sensing and Environmental Research (SLU), Kohlsteiner Str. 5, 81243 Munich, Germany

2 German Remote Sensing Data Center (DFD), German Aerospace Center (DLR), Muencher Str. 20, 82234 Wessling, Germany

3 Helmholtz Centre for Environmental Research (UFZ), Permoserstr. 15, 04318 Leipzig, Germany

4 Sino-German Research Centre for Environmental Information Science (RCEIS), Permoserstr. 15, 04318 Leipzig, Germany

5 State Key Laboratory of Resources and Environmental Information System, Institute of Geographic Sciences and Natural Resources Research (IGSNRR), Chinese Academy of Sciences (CAS), 11A Da Tun Road, An Wai, Beijing 100101, China aggravated by anthropogenic-induced climate change. To address the pressing socio-ecological challenges, various conservation and management plans and strategies have been issued, often consulted by international bodies. This article is a comprehensive overview of the current state and recent developments that have occurred in the Yellow River basin and presents and discusses current and pressing socio-ecological challenges. Additionally, we address different policy and management instruments that have been launched to ensure a long-term sustainable development within the basin.

Keywords Global change $\cdot$ Yellow River - River basin management $\cdot$ Socioeconomic development .

Environmental degradation $\cdot$ Human pressure $\cdot$ China

\section{Introduction}

Rivers around the world provide various ecosystem services and goods for human livelihoods, but also an important base for global biodiversity, being home to hundreds of flora and fauna species, of which many critically endangered. The Yellow River is one of the most important rivers in the world, spanning $5500 \mathrm{~km}$, and the sixth longest worldwide. Despite being only $15 \%$ shorter than the Nile (6700) and Amazon (6400) river, the annual water discharge and flow rate are comparatively low (Fig. 1). The Amazon has an annual discharge rate nearly 200 times that of the Yellow River. The Yellow River carries roughly 700 million tons of sediment into the Bohai Sea each year and contributes around $6 \%$ of the global sediment loads into the world's oceans (Miao et al. 2010), making the Yellow River the most sediment-laden river in the world (Fig. 1). A literature survey from Web of Science 

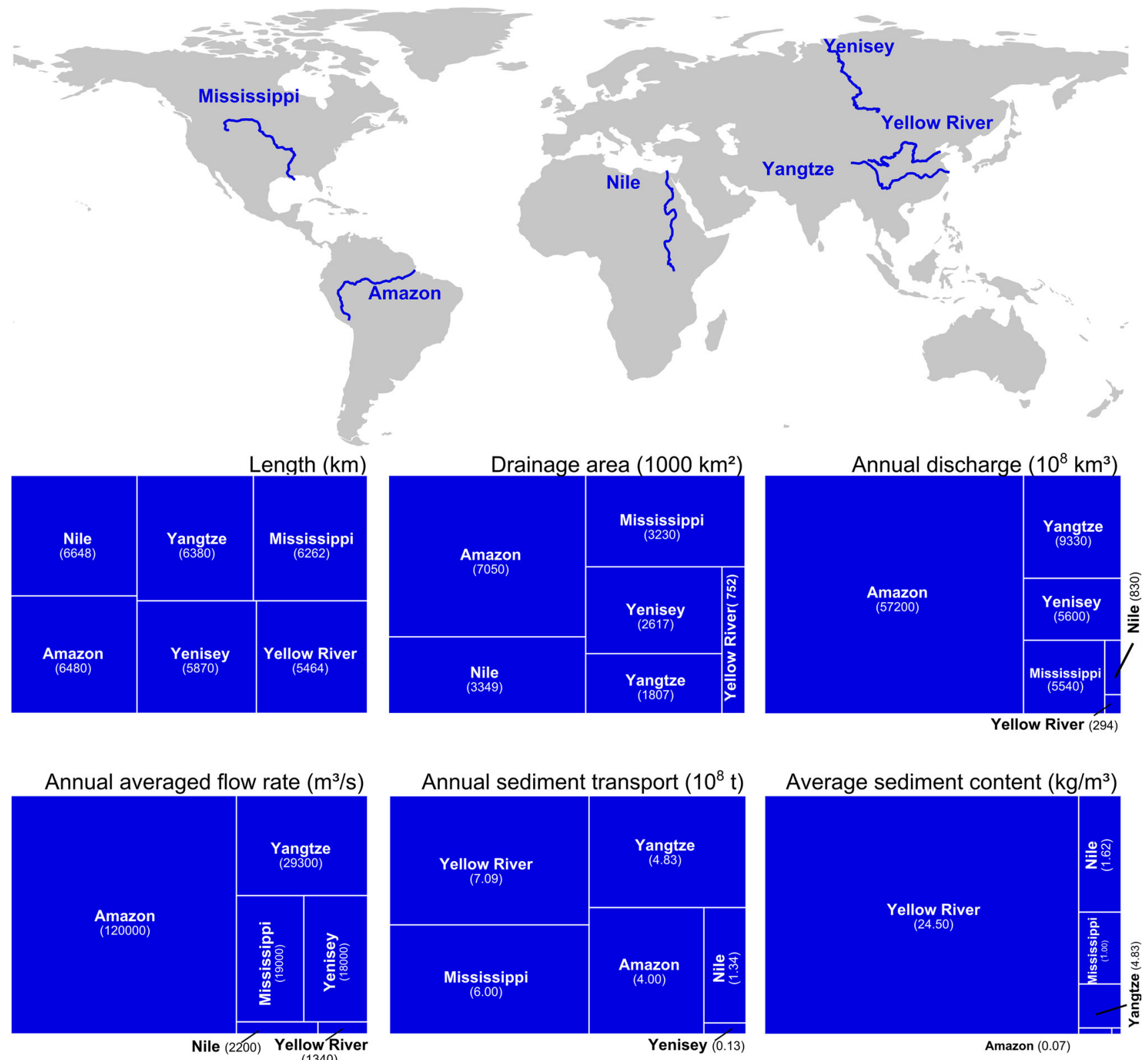

Fig. 1 Location and hydrological settings of the six longest river systems worldwide (Data combined from Fu et al. 2004; Miao et al. 2010; Nakaegawa et al. 2013; Yu 2002)

of internationally published research (only considering research articles and reviews) revealed a strong scientific focus on the Amazon (20,652), Nile (17,665), Mississippi $(11,757)$, and Yangtze (9053) catchments during the last decades. With 2853 published articles, the Yellow River received considerably less attention from the research community. However, numbers of publications are currently accelerating particularly in the last 10 years. In 2005, a mere of 400 articles were available for conducting research in the Yellow River basin region.

With its first agricultural societies having appeared 7000 years ago, the Yellow River (Chinese: Huang He) basin is designated as the "the cradle of Chinese civilization" and has played an important role in China's social, cultural, economic, and political development (Zhang et al. 1990; Lawler 2009). The second largest river basin in China encompassing an approximate area of $750,000 \mathrm{~km}^{2}$ is endowed with favorable environmental conditions, which formed the basis for early agricultural cultivation and fostered it to be the most prosperous region in ancient China (Lawler 2009). Hence, the interrelation of humans and their nature has been intensive in the basin for millennia. Very early, humans started to alter the landscape characteristics of the basin by deforesting hill slopes of the 
Loess plateau, covering an area of $280,000 \mathrm{~km}^{2}$, for agricultural production and diking the river banks in the lower reaches (Guobin 1999). Besides the provision of food and economic opportunities, this has lead to serious soil erosion, environmental degradation, and a rising riverbed, up to $10 \mathrm{~m}$ above the surrounding land, in the downstream parts (Shi and Shao 2000; Yu 2002; Chen et al. 2007; Wang et al. 2009, 2010; Piao et al. 2010). Thus, the Yellow River has also earned the epithet "China's sorrow." Over the past 1000 years, the rising riverbed, concentrated precipitation events, and the consequent shifting of the unstable river channel have led to frequent, devastating floods in the basin causing millions of casualties and unmeasured economic damage. Alone the 1887 flood, one of the last major floods, killed almost some 900,000 people and remains as one of the deadliest natural catastrophes ever recorded (Chen et al. 2012).

These days, the basin sustains a total population of almost 190 million people and plays a core role for China's remarkable economic and resource intense development with GDP growth rates exceeding $7 \%$, leading to tremendous socioeconomic dynamics, such as urbanization, agricultural encroachment, and intensification, as well as rising affluence (Webber et al. 2008; NBS 2015). Many years of intensive economic development and natural resource exploitation, however, have had their downside. Serious new environmental (e.g., decline and deterioration of ecosystems; biodiversity decline; water shortage; soil degradation; and erosion) and social problems (food security; health problems; and social disparities), which hamper a regional sustainable and successful development in the basin (Fu et al. 2004; Wang et al. 2007; Cai 2008; Miao et al. 2011; Cui et al. 2011), have been occurred. The long-term effects and in some region critical conditions are now seen by various national authorities (Government ministries, Chinese river basin authorities), international donors (World Bank, Asian Development Bank, China Development Bank), and various NGOs (WWF, IUCN), becoming active in the basin. They developed and issued various sustainable management strategies to address these diverse problems and challenges and to unite and find equilibrium between the necessary economic development and simultaneously pressing environmental conservation.

So far, internationally published research conducted in the Yellow River basin focused mainly on single scientific disciplines, such as hydrology (Zhao et al. 2012; Gupta et al. 2012; Chen et al. 2012), biodiversity (Huang et al. 2007; Qi and Fang 2007; Cui et al. 2009), geomorphology (Ma et al. 2012; Liu et al. 2013b; Kuenzer et al. 2014), and climate change and variability (Fu et al. 2004; $\mathrm{Hu}$ et al. 2012). To our knowledge, a comprehensive overview describing the physio-geographical and socioeconomic characteristics and current pressing social-ecological challenges in the Yellow River basin is lacking and does not exist in the international published scientific literature. A holistic picture of the different disciplines is necessary, particularly for such a complex system, where all components closely interact, in order to better understand the problems and pressing challenges that are currently facing the Yellow River social-ecological system.

In light of this, this article aims to present a review of the international published literature about the Yellow River basin, with an emphasis on current social-ecological challenges. The target area is characterized by a long human-environment interrelationship and thus provides an illustrative case study of how human activities can alter a river ecosystem. We will particularly address the following questions:

1. What are the current physical and socioeconomic settings?

2. How did the basin evolve, particularly during recent decades?

3. What are the key challenges affecting the Yellow River social-ecological system?

4. Which managerial and policy efforts have been introduced?

\section{The Yellow River basin: a basin in transition}

\section{Current physio-geographical and socioeconomic conditions}

Situated in the north of China, the Yellow River basin is the most important watershed in northern China $\left(32^{\circ} \mathrm{N}-\right.$ $42^{\circ} \mathrm{N} / 96^{\circ} \mathrm{E}-119^{\circ} \mathrm{E}$ ), supplying water to $15 \%$ of China's population, while producing $20 \%$ of the domestic crops (Chen et al. 2012). The river rises in the Bayan Har and Kunlun Mountains (4500 m asl) on the vast Qinghai-Tibet Plateau and with $2,500,000 \mathrm{~km}^{2}$, the world's largest and highest plateau. Known as Asian's "water tower," it is source of many of the most important river systems in Asia, including the Yangtze, Brahmaputra, Mekong, Indus, Ganges, and the Yellow River. From there, the river crosses nine Chinese provinces (or autonomous regions): Qinghai, Sichuan, Gansu, Ningxia, Inner Mongolia, Shaanxi, Shanxi, Henan, and Shandong. The river flows eastwards through the dry Ordos Desert and Loess Plateau, drains across the Yellow River and North China Plains, and discharges after $5464 \mathrm{~km}$ into the Bohai Sea, where the delta is formed (Fig. 2).

The basin's climate is controlled by the continental monsoon circulation system and transits from semiarid and arid to subhumid and humid conditions. As depicted in Fig. 2, the current average precipitation in the entire basin 


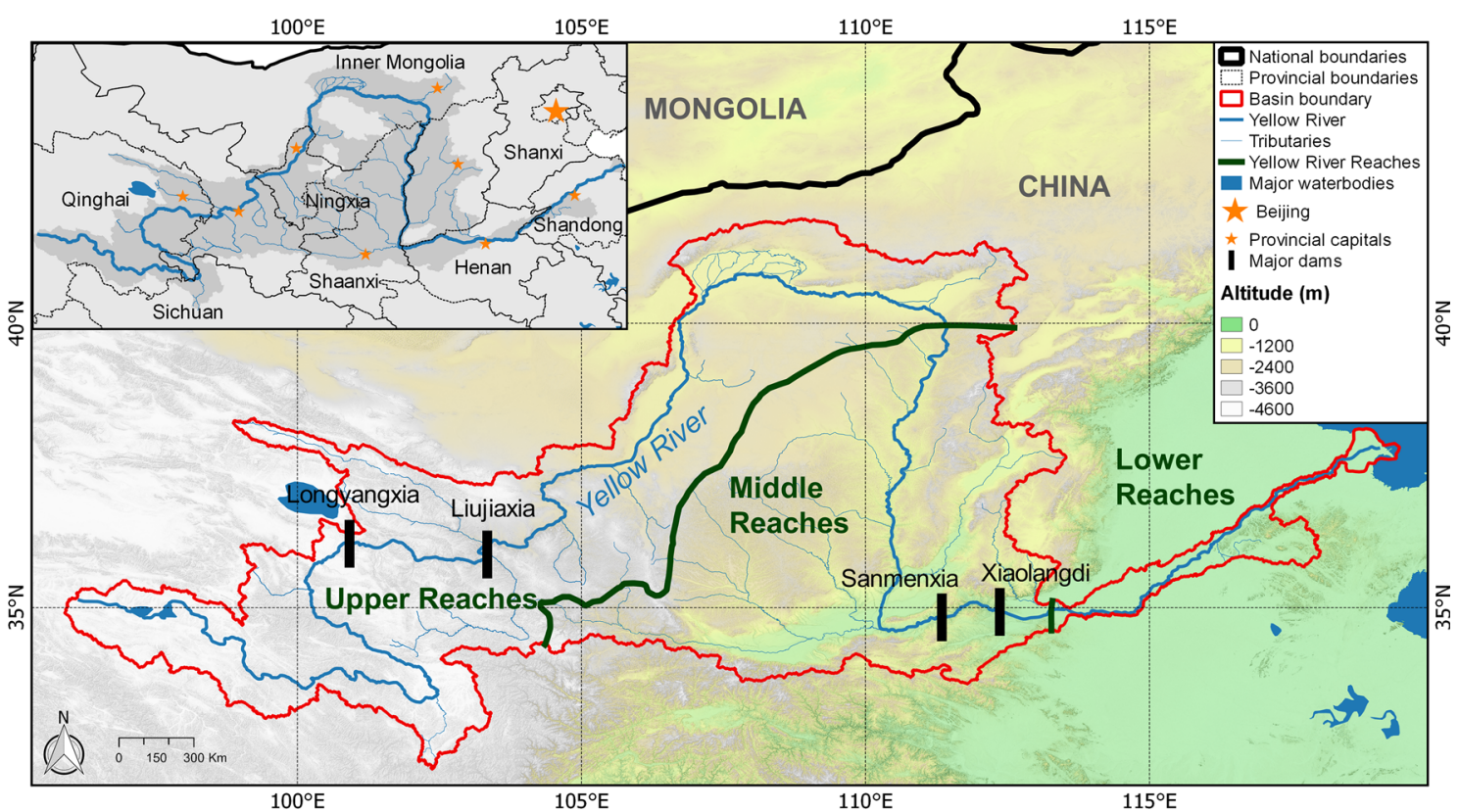

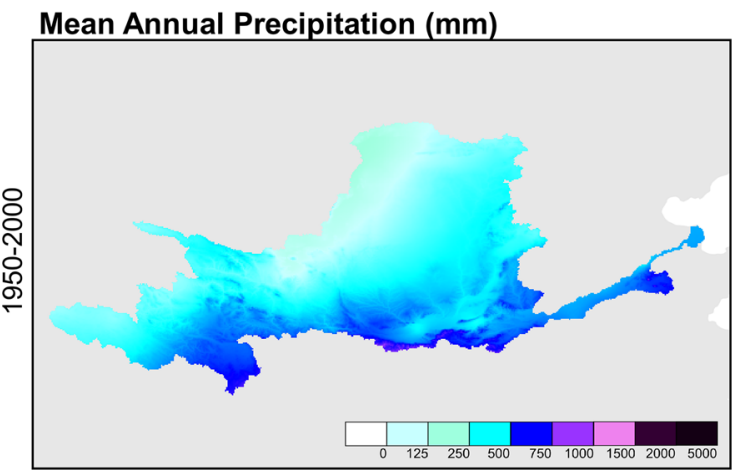

Fig. 2 Yellow River basin: the upper panel provides a physiogeographical overview (based on SRTM data) and the hydrological boundaries for the reaches. The inset map in depicts the provincial boundaries with the location of the respective provincial capitals.

equals $476 \mathrm{~mm}$, but is unevenly distributed in space and time (Hijmans et al. 2005; Zhao et al. 2008). Rainfall shows a decreasing spatial trend from southeast to northeast and is mainly concentrated in the summer season from July to September. According to its distinct climatic, hydrological, and geomorphological characteristics, the Yellow River is commonly separated into three major sections: the upper, middle, and lower reaches (Figs. 1, 2). Along its courses, particularly in the lower and middle reaches, rich quantities of rare earth minerals are abundant as well as oil, gas, and coal resources, which are becoming increasingly important for China's economic boom. Raw coal and oil extraction in the basin accounts for 50 and $25 \%$ of national production, respectively (Giordano et al. 2004; Wen et al. 2009; NBS 2015). Further, the basin is a key region for China's domestic food production and contains $129,000 \mathrm{~km}^{2}$ (15\% of the nation's arable land), in
Mean Annual Temperature $\left({ }^{\circ} \mathrm{C}\right)$

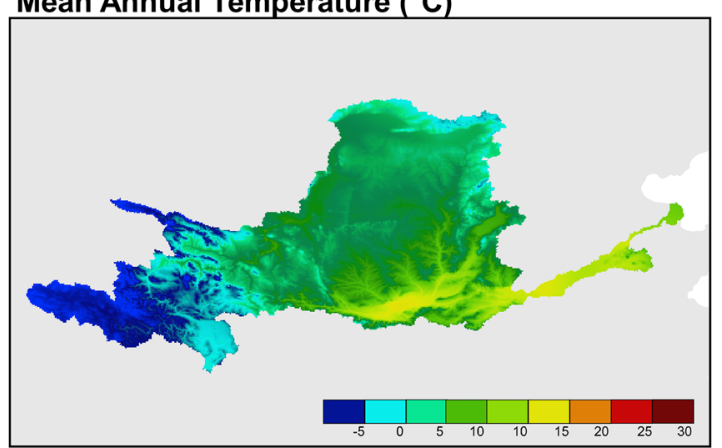

Current long-term averaged precipitation and temperature conditions are depicted in the lower panel (data derived from Hijmans et al. 2005)

which around 10 million tons of grain (2013) are produced (Cai and Rosegrant 2004; Miao et al. 2010). The majority of the cropland areas are irrigated in large-scale irrigation districts (Figs. 3, 6).

\section{Headwaters and upper reaches}

The upper reaches extend from the river's source region in the Bayan Har Mountains (4500 m asl) to the Toudaoguai gauging station near Datong (1000 m asl). With a length of around $3500 \mathrm{~km}$ and a drainage area of $368,000 \mathrm{~km}^{2}$, they constitute more than $50 \%$ of the entire basin area and contribute the majority (around $56 \%$ ) of the basin's water resources (Peng et al. 2010). The annual mean temperature ranges between 1 and $4{ }^{\circ} \mathrm{C}$, and the annual mean precipitation in the upper reaches is $396 \mathrm{~mm}$ (Hijmans et al. 2005; Wang et al. 2007) (Table 1; Fig. 2). Two counteracting 


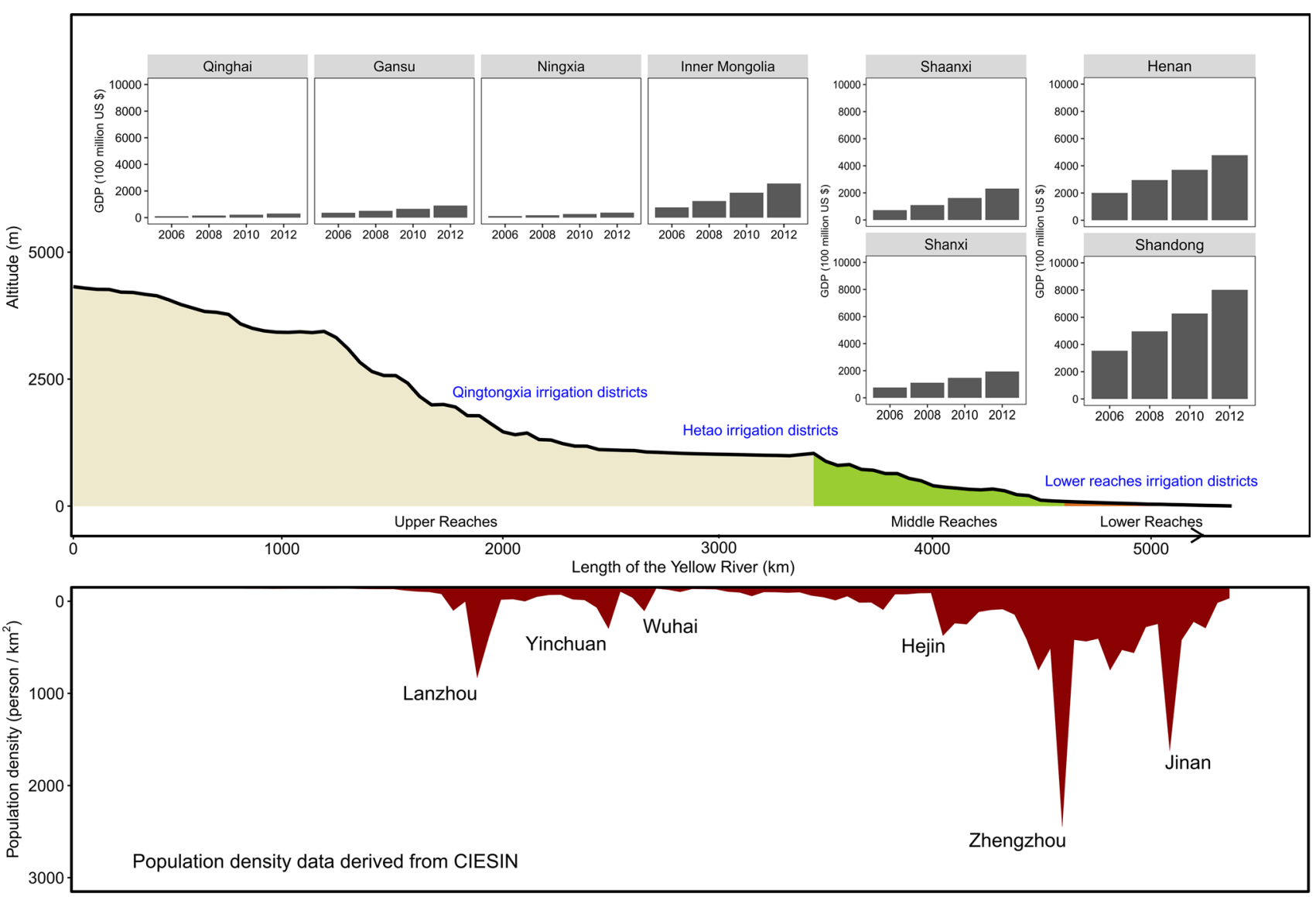

Fig. 3 Yellow River's longitudinal profile from the headwaters in the Qinghai-Tibet Plateau to the Bohai Sea. The upper panel shows the gross domestic product (GDP) per capita for each province from 2006 to 2012 (NBS 2015) and the location of the major irrigation districts. The lower panel depicts the population density along the main channel of the Yellow River
Table 1 Summary of physical and socioeconomic characteristics in the Yellow River basin (data combined from Yu 2006; Miao et al. 2010; Peng et al. 2010; Feng et al. 2012)

\begin{tabular}{lllll}
\hline & Upper reaches & Middle reaches & Lower reaches & Entire basin \\
\hline Area $\left(\mathrm{km}^{2}\right)$ & 367,898 & 362,138 & 21,833 & 751,869 \\
Length $(\mathrm{m})$ & 3472 & 1206 & 786 & 5464 \\
Altitude $(\mathrm{m})$ & $4480-1000$ & $1000-95$ & $95-0$ & $4480-0$ \\
Gradient $(\mathrm{m} / \mathrm{km})(\% \mathrm{o})$ & 10.1 & 7.4 & 1.2 & 8.2 \\
Precipitation $(\mathrm{mm} / \mathrm{year})$ & 396 & 516 & 648 & 520 \\
Average temperature range $\left({ }^{\circ} \mathrm{C}\right)$ & $1-4$ & $8-14$ & $12-14$ & $1-14$ \\
Number of primary tributaries & 43 & 30 & 3 & 76 \\
Population density $\left(\mathrm{p} / \mathrm{km}^{2}\right)$ & 70 & 210 & 750 & 230 \\
Urbanization rate $(\%)$ & 39 & 35 & 50 & 39 \\
\hline
\end{tabular}

hydro-climatic processes are predominant, which separate this area into two parts (Zhu et al. 2004). The mountainous region of the Qinghai-Tibet Plateau above Lanzhou is dominated by a cold semiarid climate with low evapotranspiration rates, and significant amounts of precipitation allow an abundant river runoff (Xu and Cheng 2002). Much of the upper reaches is defined by the Qinghai-Tibet Plateau ecoregion (Olson et al. 2001) that is dominated by vast alpine grassland steppe. Trees are present mostly in the riparian areas of the southeastern Tibetan Plateau region. Generally sparsely populated (70 persons per $\mathrm{km}^{2}$, see Table 1; Fig. 3) and with a low degree of agricultural and industrial development, the city of Xining is the most populous settlement on the plateau and used to be a key trading hub along the Silk Road. After Lanzhou, the Yellow River turns northwards into the semiarid and arid regions of the Ningxia/Inner Mongolia plains (Ordos Plateau) and the Gobi Desert, where evapotranspiration rates 
exceed precipitation rates by far, making this region a net consumer of water resources. Annual precipitation values decline below $100 \mathrm{~mm} /$ year (Hijmans et al. 2005). The centuries-long development of large-scale irrigation districts with reservoirs and channels, such as the Qingtongxia irrigation district in Ningxia or the Hetao irrigation district in Inner Mongolia, enables the planting of crops, such as wheat and oil bearing crops, and plantations (tea, melons, and pears) in a relatively dry region. The combination of low-turbidity water and limited loess resources in the upper reaches result in a low sediment yield and low suspended sediment concentration (Xu and Cheng 2002). Since 1961, large reservoirs, such as the Lijiaxia and Longyangxia reservoirs, have been constructed (Fig. 1).

\section{The middle reaches}

The middle reaches of the Yellow River, (1200 km long), continue from Toudaogui to Huayuankou, covering a drainage area of 362,138 (Table 1) and supplying $43 \%$ of the river's runoff (Zhu et al. 2004; Peng et al. 2010). The climate is semiarid/arid with slightly higher mean annual temperatures and precipitation than those of the upper reaches, with $8-14{ }^{\circ} \mathrm{C}$ and $530 \mathrm{~mm}$, respectively (Fig. 2) (Wang et al. 2007). At Toudaogui, the river bends southwards and traverses the Loess Plateau where massive, highly erosive yet fertile loess soils (up to $300 \mathrm{~m}$ thick) are abundant (Chen et al. 2007). A large number of tributaries, such as the Fenhe and Weihe rivers, drain into the main stream and contribute considerably to the river's water resources. Intensive rainfall events in summer combined with increased human disturbance and with low vegetation cover lead to high water erosion rates ranging from 20,000 to 30,000 tons per $\mathrm{km}^{2}$ per year. Enormous quantities of loess sediments reach the Yellow River and its tributaries, accounting for roughly $90 \%$ of the river's total sediment load (Wei et al. 2006; Chen et al. 2007). Several millennia ago, humans started to transform vast areas covered by forests, shrubs, and grasslands on the Loess Plateau into arable land in order to satisfy growing food demands, resulting in severe soil erosion. The abundance of natural resources (e.g., coal) makes the middle reaches more densely populated than the upper reaches (210 persons per $\mathrm{km}^{2}$ ) (Fig. 3). The Sanmenxia reservoir constructed with Russian aid was the basin's first large dam and began operating in 1957. The multi-purpose Xiaolangdi reservoir was the last major dam project in the basin commencing in 1999.

\section{The lower reaches and the Yellow River Delta}

Downstream from Huayuankou, the Yellow River flows for $786 \mathrm{~km}$ on the flat North China Plain to the Bohai Sea.
Owing to intense river management in the past to control the floodplain inundation, the river has been confined with artificial levees and now flows in a relatively narrow but stable channel between 45 and $60 \mathrm{~m}$ (Giordano et al. 2004). However, this measure has led to an unforeseen phenomenon referred to as the "suspended" or "hanging" river ( $\mathrm{Yu}$ 2002). Due to the high concentration of suspended material in the river, accompanied with reduced water discharge and velocity, severe sediment deposition appeared in the lower reaches, raising the riverbed up $10 \mathrm{~m}$ above the immediate surrounding alluvial plains (Wang et al. 2007; Peng et al. 2010). Therefore, the inflow is greatly reduced, and hardly, any tributaries can join it, except for the Yiluohe and Qinhe Rivers in the upper part of the lower reaches. Thus, the contribution of water resources in the lower reaches is comparatively low with just $3 \%$ (Zhu et al. 2004). Generally, the lower river section $\left(649 \mathrm{~km}^{2}\right)$ is influenced by a more humid climate with mild temperatures $\left(12-14{ }^{\circ} \mathrm{C}\right)$ and the highest precipitation values $(670 \mathrm{~mm})$ among all the reaches (Fig. 2) and therefore a key region for food production, where vast agricultural fields of stable staple crops (winter wheat and maize) are cultivated (Deng et al. 2006; Nakayama 2011). The present Yellow River Delta, one of the largest river deltas in China, is located in the northern part of Shandong Province and covers an area of $7870 \mathrm{~km}^{2}$, inhabiting around 5.4 million people (Qi and Fang 2007). The high sediment quantities (1.05 $\times 10^{7}$ tons annually) and deposition rates form a dynamic, continuous, and fast growing natural delta at the river mouth (Cui et al. 2009). The delta contains diverse ecosystems of unique assemblages of floral and faunal species, but is also economically important, accounting for a substantial proportion of China's GDP via the exploitation of China's second largest oil field: Shengli oilfield ( $>4.6$ billion tons reserve) (Kuenzer et al. 2014) and important base for crop and aquaculture (Ottinger et al. 2016).

\section{Recent socioeconomic and landscape dynamics}

As one of the global centers of ancient human civilization, the Yellow River has a long and intense history of interactions between humans and their environment. In recent decades, the Yellow River basin has witnessed incredible developments, just like all of China. Since the late 1970s, fundamental economic reforms toward a more liberalized, market-oriented system and the opening to international markets have been rewarded with increasing foreign direct investments, allowing for a remarkable expansion of the domestic economy, fostering industrialization, agricultural intensification, urbanization, and affluence in the basin (Tisdell 2009; UNDP 1999). Industrialization and hence the GDP in the basin has tremendously at annual growth 
rates between 7 and $10 \%$. Within the economic sectors, agricultural share of GDP has been reduced from 30 to $10 \%$ (1990-2012), since the industrial and service sectors have developed faster. In terms of employment, however, agriculture is still the dominant sector (NBS 2015). The decentralized household responsibility system, a major economic reform launched in the early 1980s, allowed farmers to take responsibility for their own revenues and losses. This policy triggered an increased and intensified agricultural production, as well as higher rates of rural urbanization and better welfare (Webber et al. 2008). In 30 years, the average grain yield almost tripled from 2 to 5 tons per ha (Piao et al. 2010). These reforms were urgently needed to maintain an adequate food supply to match the needs of a growing population and rising affluence.

In the past 100 years, the basin's population has more than quadrupled from 50 to 190 million, but remained stable in the last decade (Fig. 4), whereas urbanization rates doubled between 1980 and 2006, from 18 to $40 \%$ (NBS 2015). Basin-wide, however, about $75 \%$ of the residents are still living in rural areas (Fig. 4). The long-term goal of the government is to transform China from a nation of peasant farmers into a modern, urbanized country.

The increase in agricultural production (Fig. 4) in the Yellow River basin has been achieved mainly through the increased use of fertilizer (70\% increase since 2005, NBS 2015), expansion of agricultural areas (10\% since 2002, NBS 2015), and the development of water resources by installing large-scale irrigation facilities, such as channels, wells, and reservoirs. The irrigated area expanded from $8000 \mathrm{~km}^{2}$ in 1949 to around $75,100 \mathrm{~km}^{2}$ by 2000 , an increase in more than $800 \%$ (Cai and Rosegrant 2004; Nakayama 2011). The earliest irrigation facilities date back several centuries, but the majority of large-scale irrigation districts were established during the last 50 years (Fu et al. 2004; Yang and Ishidaira 2010). Currently, $50 \%$ of the basin's arable land is irrigated and this number is expected to continue to rise over the next decades due to predicted increasing demand for agricultural commodities (Zhu et al. 2003; Ringler et al. 2010). In particular, lower reaches provinces have experienced a significant intensification of agricultural production in recent decades, with an increase in grain production by $25 \%$ during the last 15 years (NBS 2015). However, the transition from an agrarian to an industrialized society has not occurred equally throughout the basin. As can be seen in Fig. 4, coastal provinces have developed much faster than the hinterland, causing economic and social disparities (Wen et al. 2009). Industrialization and urbanization occurred mainly in Shandong province, but also took place in Henan and Shanxi in the lower-middle reaches.

Owing to these tremendous socioeconomic changes and the increased demand for natural resources, the basin's characteristic and landscape features have evolved. During recent decades, a series of dams and reservoirs (3147 in 2007) with a total storage capacity of around $72 \mathrm{~km}^{3}$, exceeding the annual water discharge (Ran and Lu 2012), have been constructed, scattered throughout the mainstream and the tributaries of the Yellow River but located mainly in the river's upstream catchment (Fig. 2). These facilities have fragmented and regulated the river system, not only changing its hydro-physical setting but also influencing rural livelihoods (Wang et al. 2007; Yang et al.

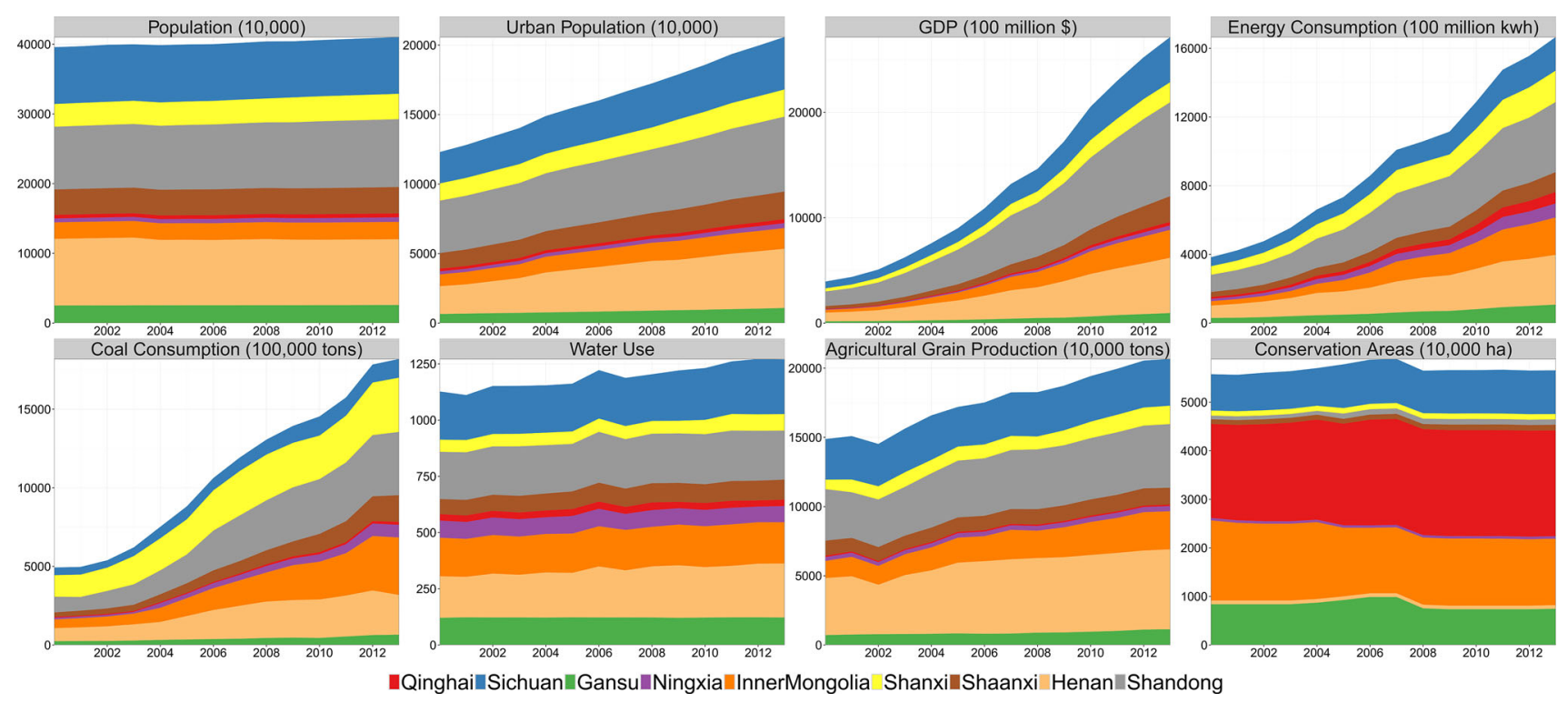

Fig. 4 Temporal development of major socioeconomic statistics derived from the National Bureau of Statistics of China (NBS 2015) 
2008; Ouyang et al. 2010; Kuenzer et al. 2013). The main purposes for this massive infrastructure development were to generate hydroelectric power, control floods, alleviate severe channel sedimentation in the lower reaches, control water flow to avoid desiccation, and provide water resources for agricultural, industrial, as well as domestic use. However, recent studies have demonstrated that dam operations have impacted the water and sediment discharge pattern, resulting in physical, geomorphological, and ecological changes in the lower reaches, the coastal area including the delta, and the Bohai Sea (Li et al. 1998a, b; Xu 2002a; Wang et al. 2007). Figure 5 gives an overview about the temporal variation of sediment load and water discharge and shows clearly the impacts on the hydrophysical settings after the operation start of a dam.

Besides the socioeconomic development, recent land use polices have greatly modified the landscape within the basin. To counteract the environmental degradation and rural poverty, the Chinese government central perceived the social and economic costs of the environmental degradation and launched nationwide, state-funded schemes such as the "Grain-for-Green" program (GfG), one of the largest conservation projects worldwide, with the Yellow River basin declared as a target region, or the "National Forest Conservation Program" (NFCP). Another major conservation and restoration program, funded by the World Bank, was the "Loess Plateau Watershed Rehabilitation Program" launched in 1996. All initiated projects target specifically degraded landscapes with a low vegetation coverage, enhancing the ecologically status (see "Restoration and conservation management efforts toward a more sustainable basin" section for detailed explanations).

The aforementioned anthropogenic activities have been comparatively weak in the upper reaches due to unfavorable natural conditions and a lack of natural resources. Hence, land use and land cover change progressed rather slowly during recent decades. Currently, the upper reaches are more strongly affected by changes in natural conditions, such as variations in temperature and precipitation patterns. There has been an apparent trend of expansion of the Gobi desert, with the area affected by desertification increasing annually by around $2 \%$ (Dong et al. 2009; Hao et al. 2012). The predominant grassland ecosystems in the arid and semiarid regions are extremely fragile, and their
Fig. 5 Temporal variation of water and sediment discharge at Lijin gauging station, the last gauging station before the Yellow River enters the Bohai Sea, (Shandong province) from 1950 to $2008(b, c)$. a Shows erosion and accumulation pattern of sediments in the lower river channel.

Furthermore, the respective start of operation of the four major dams is highlighted. The data are supplied by the Yellow River Conservancy Commission (YRCC) and by the Ministry of Water Resources (MWR)
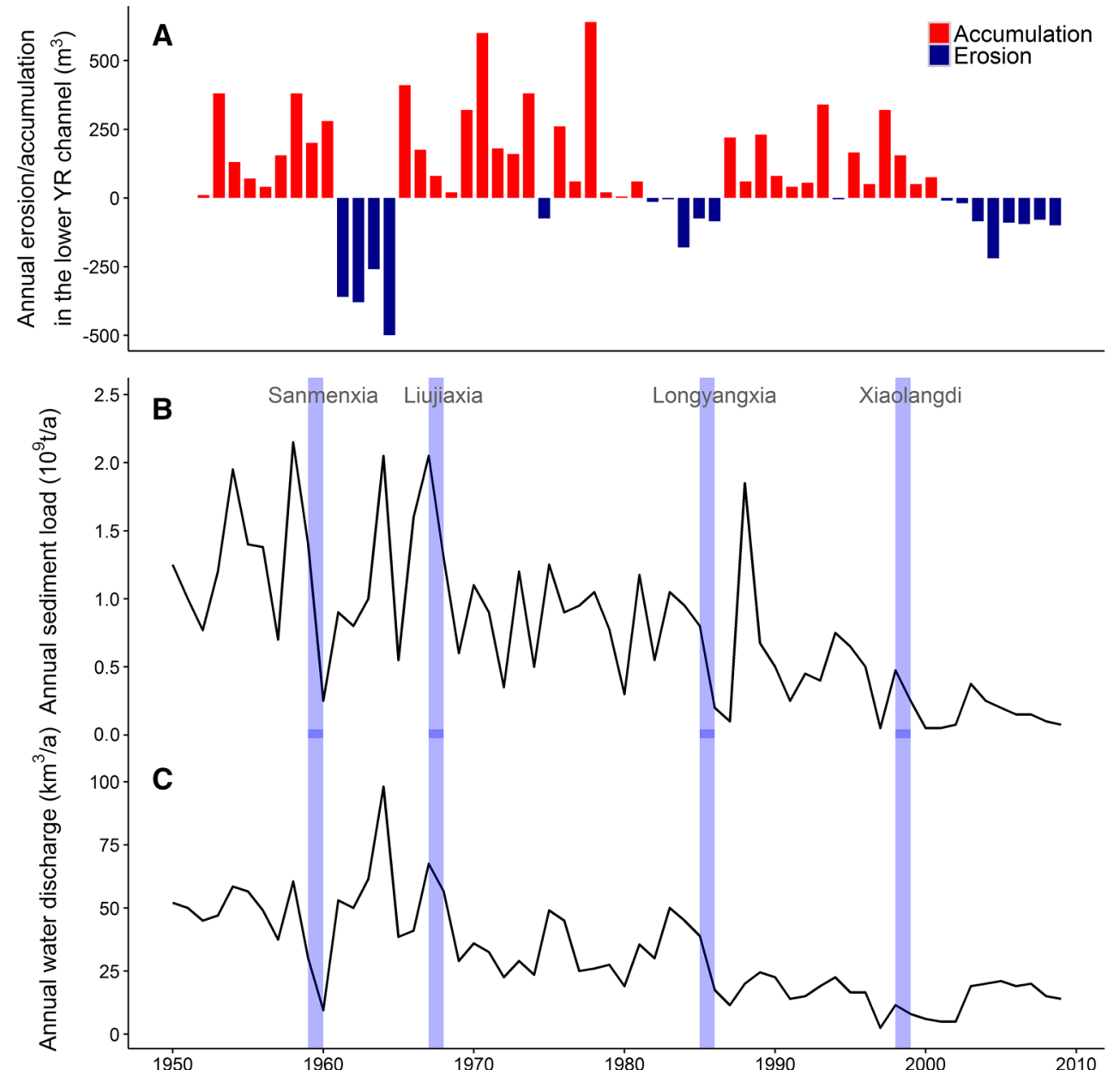
capacity for regeneration capacity is low. Thus, they are very sensitive to climate variations and human disturbance (Ni 2011). Although the human influence in the landscape is weak, a clear trend of decline and serious deterioration of natural vegetation has been obvious in recent decades (Cui and Graf 2009; Dong et al. 2009).

Climate variations and increasing demand for resources have resulted in a steady decline of water discharge and sediment load in the lower reaches over the past 50 years (Fig. 5b, c). Human activities (water diversion for agricultural and industrial use, hydropower engineering, water and soil conservation, land use change, and population growth) are thought to be the major factors for this development (Wang et al. 2007, 2012; Peng et al. 2010; Miao et al. 2011). The surface water used by humans for agriculture, industry, and domestic use was $7.4 \mathrm{~km}^{3}$ in 1949 , but increased to $30.8 \mathrm{~km}^{3}$ in 2011 (YRCC 2013). Sediment interception by dams and massive soil conservation efforts have mainly contributed to the rapid decline of sediment load to the river. Peng et al. (2010) estimated that soil conservation practices accounted for $40 \%$ of the decline, sediment trapping by dams for $30,10 \%$ are attributed to human activities in the lower reaches, and a decrease in precipitation is responsible for the remaining $20 \%$. It is estimated that the sediment discharge to the Bohai Sea has been reduced by $90 \%$ since the 1960s level of 1.09-0.15 gigatons per year (Milliman and Meade 1983; Wang et al. 2010). Similar trends in declining water and sediment discharge, substantially due to human activities, can be observed in other large river systems in China, such as the Yangtze River or the Pearl River, albeit not to the same extent as in the Yellow River (Zhang et al. 2006; Wu et al. 2012).

\section{Current and pressing social-ecological challenges}

\section{Biodiversity decline and environmental degradation}

The complex and heterogeneous environmental conditions that dominate in the extensive basin form a wide range of different and fragile ecoregions, encompassing a unique floral and faunal species, many of them endangered. The long history of deforestation and overgrazing, particularly in the middle and lower reaches, has turned large areas into degraded and fragmented landscapes, which used to be covered by dense vegetation of temperate and evergreen forests (Guobin 1999). The recent intensification processes, as well as human-induced climate change, present in the basin, are currently threatening the remaining ecosystems and species. Large connected deciduous forests are present in Shanxi province (Lüliang Mountains), the Ziwuling Mountains, and in the Qinling Mountains (both Shaanxi
Province) with forested areas of around 2800, 2300, and $3000 \mathrm{~km}^{3}$, respectively (Shi and Shao 2000; Zhang et al. 2009). The latter inhabits still a significant population of endangered giant pandas. Habitat loss and fragmentation are the most serious threats to pandas, and the remaining population of around 200 is now restricted to few isolated patches (Loucks et al. 2003). The basin still consists large wetland resources and includes seven internationally important wetlands designated as Ramsar sites, such as the Shandong Yellow River Delta Wetland $\left(1530 \mathrm{~km}^{2}\right)$, Eling Lake $\left(610 \mathrm{~km}^{2}\right)$, or the Zhaling Lake $\left(650 \mathrm{~km}^{2}\right)$. According to the last IUCN red list assessment, amphibians, which heavily depend on such ecosystems, remain highly threatened throughout the basin (Fig. 6) (IUCN 2015). Also many avian species, such as the red-crowned crane, require connected and intact wetland habitats (Xu et al. 2004; Wang et al. 2013). Particularly, the lower reaches and the delta, where the influence of intensive agricultural and industrial practices has been most prominent, experienced a strong decline and deterioration of natural ecosystems, including those of central and coastal wetlands with a decline of more than $50 \%$ since 1995 (Ottinger et al. 2013). Not only did direct land conversion, but also landscape fragmentation processes accelerated, mainly via the construction of industrial facilities, such as oil and gas pumps (Yue et al. 2003; Wang et al. 2009; Bi et al. 2011) which almost quadrupled from 340 to 1150 in the last 20 years (Kuenzer et al. 2014).

Facing, the need to balance levels of sustained economic development in accordance with environmental conservation and sustainability, numerous protected areas have been established over the past decades to protect the remaining ecological resources, covering a total area of $100,000 \mathrm{~km}^{2}$, which represents $7 \%$ of the basin's area (IUCN and UNEP-WCMC 2015). The spatial distribution of protected areas can be seen in Fig. 6a. To restore and protect the newly formed remaining and still-prograding wetland ecosystems in the Yellow River Delta with their rare and endangered bird and plant species, the central government founded the Yellow River Delta Nature Reserve in 1992, which has been declared as a protected Ramsar Wetland site in 2013 (Kuenzer et al. 2014). Another major conservation area established in 2000 is the Sanjiangyuan National Nature Reserve on the Qinghai-Tibet Plateau, and it is the second largest natural reserve in the world, encompassing a total area of approximately $152,000 \mathrm{~km}^{2}$ with an emphasis on sensitive alpine swamp meadow and natural habitat of the unique wildlife in the region, and to promote sustainable economic development in the region (Li et al. 2012). But the increasing demand for fast and cheap energy accelerate the expansion of opencast coal mining activities, even encroaching in this protected area (Xu et al. 2012). Ecosystems are further harmed by the 


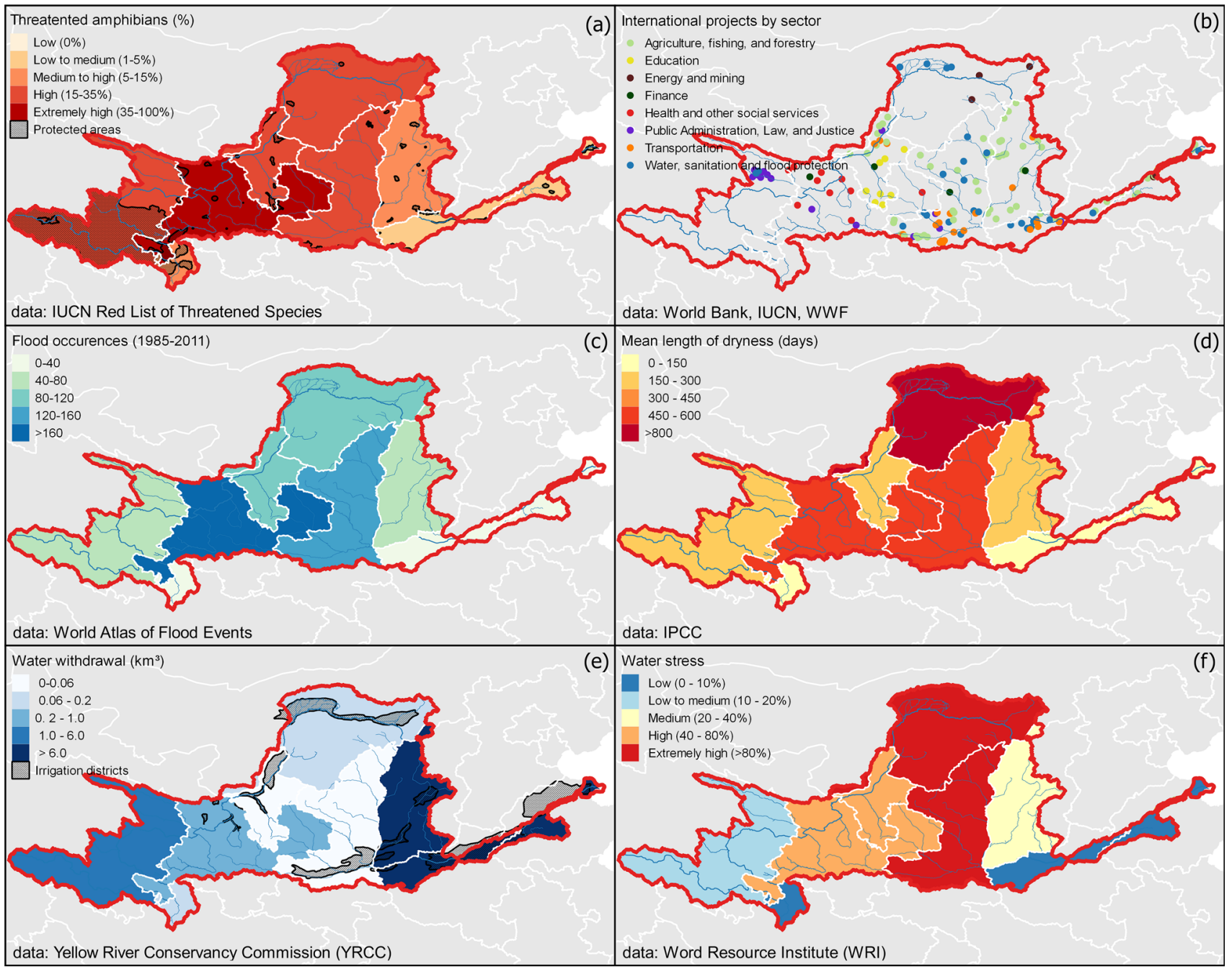

Fig. 6 Province wise distribution of a threatened amphibian species (IUCN 2015) and protected areas (IUCN and UNEP-WCMC 2015), b conducted projects by international partners sorted by sector,

c Flood occurrences from 1085 to 2011 (Brakenridge 2016), d mean length of drought days from 1901 to 2008 (IPCC 2013), e water withdrawal in $\mathrm{km}^{3}$ for 2011 (YRCC 2013), and f baseline water stress

release of various pollutants like oil, detergents, heavy metals, nitrogen and phosphate from fertilizer (Xia et al. 2002; Hui et al. 2009).

\section{Flooding and sedimentation}

The Yellow River has had a long history of flooding with more than 1000 floods in the last 4000 years (Chen et al. 2012). Much of the problem stems from the elevated river bed (Shi and Shao 2000). These devastating floods have caused millions of casualties, weakened social stability, and diminished national prosperity. Large efforts in flood control and mitigation have been made, including the raising and reinforcement of existing levee structures, the expansion of flood retention areas in the lower reaches, the construction and operation of large reservoirs in the basin such as the Xiaolangdi and Sanmenxia reservoir in the middle reaches, and soil erosion and sedimentation control

on the Loess Plateau (Wu et al. 2004; Li 2005). Since 1985, more than 120 floods in Shaanxi and 160 in Gansu Province have been counted in the middle and upper reaches as depicted in Fig. 6b. Either induced by heavy rainfall events in summer or by ice jams in early spring, the contemporary flood events are rather localized and occur on small spatial scales (Jiang et al. 2008; Chen et al. 2012).

Flood prevention is closely related to sedimentation control. Since the late 1970s, large efforts in soil conservation and ecosystem restoration have been implemented by the Chinese government to reduce the severe soil erosion, such as the building of check dams, and creation of level terraces, followed later by vegetation restoration, either by selective tree planting or natural recovery by land closure (Chen et al. 2007; Miao et al. 2010, 2011). Until 2011 , a total area of $20,000 \mathrm{~km}^{2}$ sloped land was converted to terraces (Miao et al. 2012). By altering the micro-topography, intercepting precipitation, and improving the 
infiltration rate, the surface runoff and sediment transport into the river have been reduced. These practices in the middle reaches, in combination with the successful joint operation of the Sanmenxia and Xiaolangdi reservoir of flushing water and sediment annually, the so-called water and sediment regulation scheme, has stopped the strong deposition tendency in the lower reaches and we can observe channel scouring instead (Fig. 5a). However, the high suspended sediment load has been the dominant factor controlling the delta evolution over the last 150 years. Prior to the 1970s, the delta extended rapidly into the Bohai Sea (Li et al. 1998b). The reduced sediment supply in turn is increasing coastal erosion and decelerating and even stopping delta progradation altogether. Sediment load is expected to decline even further in the future. Therefore, it is important to find a balance between controlling deposition in the lower river channel on the one hand and ensuring that a sufficient amount of sediment is conserved, on the other hand that tide and wave erosion are kept at a minimum.

\section{Water scarcity}

The basin is one of the most water-stressed regions in China, as it represents only $2 \%$ of China's naturally available freshwater, but is supposed to supply water for $15 \%$ of China's total population (Xia and Pahl-Wostl 2012). Available water quantities reach only $430 \mathrm{~m}^{3}$ per capita, which is by definition far below the threshold $\left(1000 \mathrm{~m}^{3}\right)$ for chronic water scarcity and one of the lowest per capita water supplies worldwide (Falkenmark and Widstrand 1992; Cai and Rosegrant 2004; Ringler et al. 2010). Hence, water scarcity is a crucial issue with profound impacts on agricultural and industrial production, society, and the prevailing ecosystems, which can cause regional bottlenecks for sustainable development in the basin. Water resources are limited naturally due to the prevailing climatic and hydrological conditions and are unevenly distributed in space and time (see precipitation diagrams in Fig. 1) (Deng et al. 2006). But more importantly, water demand and consumption by humans have been increased and almost tripled from $12.2 \times 10^{9} \mathrm{~m}^{3}$ (1950) to $35.1 \times 10^{9} \mathrm{~m}^{3}$ (2008), resulting in a declining river discharge, particularly in the lower reaches from $52 \mathrm{~km}^{3}$ (1950) to $15 \mathrm{~km}^{3}$ (2011), a decline of more than $70 \%$ (Cai and Rosegrant 2004; Ringler et al. 2010; Miao et al. 2011; YRCC 2013) (Fig. 5c). Owing to the extensive water extraction, the Yellow River experienced a novel situation in the 1970s: The river ceased to flow in the lower reaches during the irrigation period in spring (Yang et al. 2004a, b), peaking in 1997 with 226 consecutive days of no-flow and a desiccated river channel around $700 \mathrm{~km}$ from the river mouth, even failing to reach Shandong province (Xu 2002b; Cai and
Rosegrant 2004; Liu and Xia 2004). These low-flow and noflow events, however, are of national concern, as access to drinking water for 1.3 million people was restricted, oil wells in the delta region were also forced to close, resulting in a direct economic loss estimated to be $6.5 \times 10^{8}$ US $\$$ (Li 2005). As water is a finite resource in the basin, the disparate consumption of one user automatically affects the availability to another user. Competing demands trigger conflicts between geographical regions on the one hand and economic sectors on the other hand. Although the Yellow River does not cross international boundaries, the Chinese provinces themselves pursue divergent objectives and interests, leading to sharp competition between upstream and downstream users (Barnett et al. 2006). Given the spatial imbalance between water supply and demand, the Yellow River basin is a classic example of an upstreamdownstream water allocation problem. The majority of the water is generated in the upper reaches, but population, urbanization, and industrial development are not yet at comparable level (Figs. 3, 4). The economy in the upstream provinces is mainly based on agricultural production. The high abundance of water resources leads to the waste of water in agricultural production, as farmers have constructed their own canal and irrigation system and are unwilling to divert water from them or save water since their production would be adversely affected. Farmers, consuming more than $70 \%$ of the basin's water resources (YRCC 2013), allocate more water to their own production than they are entitled to by law (Lohmar et al. 2003; Cai 2008). Consequently, the downstream provinces with a higher share of industrial production, such as Shandong and Henan, suffer severely from water shortage and in annual flow interruptions.

\section{Food security, social stability, and human health}

Future food security is a subject of concern. Although domestic food production has remarkably grown over the last two decades by more than $20 \%$ (NBS 2015) (Fig. 4), year-to-year fluctuations of food supply and prices are significant. Food self-sufficiency has been and will continue to be the main goal of China's agricultural policy to reduce the reliance on international trade markets (Ghose 2014). Large areas $\left(75,000 \mathrm{~km}^{3}\right)$ in the Yellow River basin are irrigated, and stable harvests require constant and sufficient water availability (NBS 2015). The aforementioned drying-up events in the lower reaches, caused severe reduction in grain production in Shandong province and threatened subsistence of many peasant farmers. As main water consumer the agricultural sector is very sensitive to water shortages, and the availability of water for agriculture is closely related to industrial and domestic demand. Authorities tend to give a preferential treatment to 
industrial and domestic water users rather than to agriculture since the latter has a comparatively low economic output (Lohmar et al. 2003). Particularly in provinces in the lower reaches (Shandong, Henan) where industry and urban development are predominant, there has been a transfer of resources, including of water, labor, and capital, away from agricultural purposes without any financial compensation by the government. Still, most people (35\% in 2014, NBS 2015) in the basin work in the primary sector and live in rural areas and therefore depend heavily on water for agricultural irrigation for their livelihoods. These rural citizens usually have fewer alternatives for revenue generation than urban ones (Cai 2008). For many locals, fish is the main protein source, but as a result of human intervention, including overfishing, pollution, and disruptive dams built along the river, the number of fish species in the river has been reduced by $30 \%$ and that of the river's fish catch by $40 \%$ ( $\mathrm{Li} 2005$ ). As one of China's main agricultural production zones, the Yellow River basin faces great challenges of feeding its population with declining land and water resources from competing nonagricultural users. Further environmental degradation and pollution, strong income growth, and population growth stimulate demand for agricultural products.

In recent years, the surface and ground water quality of the Yellow River and its tributaries have deteriorated as a result of increasing industrial, agricultural, and domestic sewage. Many river sections nowadays are far below the minimum standards. In 2011, the Yellow River Conservancy Commission (YRCC), the main river basin authority, reported that more than $70 \%$ of the river's water resources are polluted and that of them one-third are unfit for any use, including for drinking, industrial, or even agricultural use due to the high level of pollution (YRCC 2013). The waste from expanding cities is directly released into the river system, and lower flow rates have reduced the capacity to dilute untreated wastewater. Although water treatment has improved, a large quantity of domestic and industrial effluents are still drained untreated into the river (Kuenzer 2007). Water pollution not only leads to a decline in environmental quality, but also threatens human health. High rates of cancer have occurred across the basin, but the highest concentrations of these so-called cancer villages are seated in the lower reaches. Riparian people either consume the contaminated water directly or eat food that is contaminated with heavy metals due to their accumulation through trophic food transfer (Cui et al. 2011). These circumstances mainly affect the poor local riparians who depend heavily on the resources provided by the river. Water and air contamination from industrial pollution is believed to be the major cause of cancer, but nonpoint source pollution, mainly caused by agricultural areas and soil erosion, is also a critical issue as these pollutants are more difficult to control. Farmers substantially intensified agricultural production by applying organic and inorganic fertilizers as well as pesticides to their fields, with the consequence that in high-rainfall and irrigation areas, large residues are polluting the river (Chen et al. 2003; Ju et al. 2004; Zhao et al. 2009).

\section{Climate change and variability}

The Yellow River basin faces multi-faceted challenges stemming from human-induced climate change and variability and is increasingly affecting many aspects of human livelihoods and environmental conditions. Particularly, all aforementioned social and ecological challenges in the basin emanating from climate change are expected to be further exacerbated. Consistent with the global trend, temperatures have increased in the basin. Since the 1960s, the average air temperature has risen by more than $1{ }^{\circ} \mathrm{C}$, and even more in the Qinghai-Tibet Plateau (Tang et al. 2008; Hu et al. 2012). Several studies revealed permafrost degradation across the Qinghai-Tibet Plateau caused by warming during the last decades, and a continued thawing may lead to increasing emissions of greenhouse gases $(\mathrm{Li}$ et al. 2008; Wu et al. 2015). Precipitation patterns have also changed throughout the entire basin: precipitation quantities have generally decreased, but the decline is mainly concentrated in the Loess Plateau in the middle reaches, whereas the Yellow River's source region has received higher quantities of rain (Tang et al. 2008). Another feature that has a direct influence on regional precipitation is the occurrence of El Niño/Southern Oscillation (ENSO) events. This phenomenon has been known as a dominant force in regional climatic pattern, causing strong variability. Since the 1980s, the number and frequency of global ENSO events have increased. Low-level precipitation years in the basin can be directly linked to moderate and strong ENSO events (Wang et al. 2006). According to the scientific assessments by the Intergovernmental Panel on Climate Change (IPCC), temperature may increase in the basin between $2-3{ }^{\circ} \mathrm{C}$ (RCP4.5 pathway with emission peak in 2040) and $4-5{ }^{\circ} \mathrm{C}$ (RCP8.5 pathway with continued emission) by 2070 (Fig. 7) (Hijmans et al. 2005; IPCC 2013). Rising temperature is predicted to be more dominant in the high altitude alpine headwater regions and the very arid northern part of the basin (Ordos Plateau). Precipitation trends differ depending on the greenhouse gas trajectory, but are congruent in a further drying of the alpine headwater region. This is worrisome as the majority of the basin's water resources is originating in this region, resulting in a long-term decline of river runoff in an already water scarce region. Changes in seasonal variability may change, and extreme precipitation events are predicted to be more frequent. 

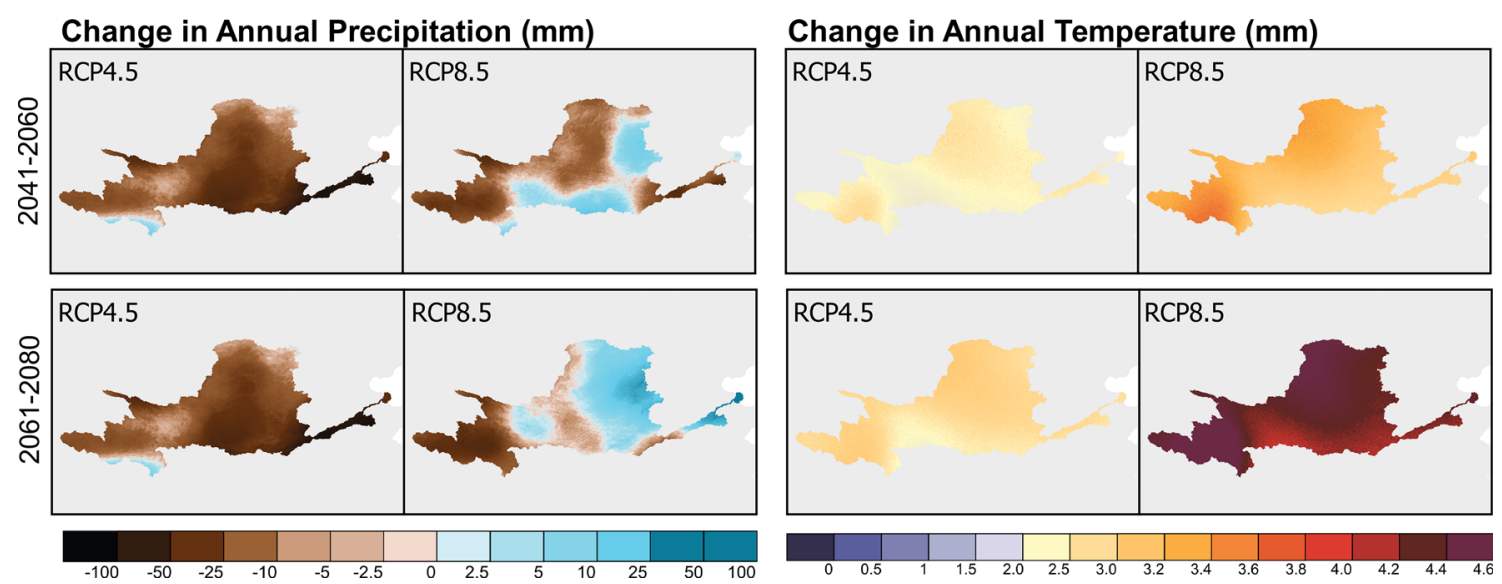

Fig. 7 Change in average precipitation (left panels) and change in (right panels) average surface temperature relative to 1950-2000 conditions under the RCP4.5 (left) and RCP8.5 (right) scenario based on MPI-ESM-LR model

The impacts of climate change are diverse due to the basin's vast extents and its different ecoregions (alpine tundra, desserts, and low-lying coastal areas). The Yellow River basin is predominately characterized by agrarian structures, and more than $50 \%$ of its population is living in rural areas, of which the majority depends on agriculture for their livelihoods. There are contradictory studies predicting the effects of climate change on crop production. Studies concluded a reduction in agricultural yield by 10-20\% (Tao et al. 2008), whereas Tao and Zhang (2013) suggested an increase in winter wheat yields due to warmer winter conditions. Extreme events are expected to increase with negative effects on agricultural production (IPCC 2013). Heat waves, heavy precipitation events accompanied with flooding, and storms could lower crop production (IPCC 2013). As a consequence, rural impoverishment could be exacerbated as those usually have limited capacity of adaption to the negative impacts. Also, the Yellow River Delta region is extremely vulnerable to climate change impacts. Land subsistence, as a result of groundwater withdrawal, in combination with sea level rise (projected to increase by $35 \mathrm{~cm}$ until 2050) is an immediate threat to the dense coastal population and economy (Syvitski et al. 2009; Kuenzer et al. 2014). Coastal wetlands habitats are the first of defense against climate change impacts, including storm surges and coastal erosion processes, making the maintenance of healthy coastal wetland ecosystems essential.

\section{Restoration and conservation management efforts toward a more sustainable basin}

Numerous stakeholders in the Yellow River basin have seen and are now seeing the long-term effects of the irrational exploitation and use of natural resources and are facing serious environmental and social challenges. Even international media have frequently reported about the prevailing challenges that are occurring in the basin. Phrases such as National Geography's "The Dying River" or the New York Times's "China's Troubled River" and "Cancer Villages" were used to describe the existing problems and highlighted that the focus on economic growth and the consequent over-exploitation of natural resources had taken their toll, posing various threats to both the environment and society (Gilliam 1994; Casey and Klaine 2001; Zhao et al. 2009). In response, several national reforms and policies have been issued to address these diverse problems and challenges at almost all hierarchical levels, from national to local (Liu et al. 2012). Public participation, in form of nongovernmental organizations (NGOs), is becoming more and more important. Since 1994, where the first NGO was founded, the number has increased to more than 350,000 in China (Economy 2010). Also, many international bodies, such as the World Bank, Asian Development Bank, the World Wildlife Fund (WWF), or the European Union, became more active and consulted and financially supported various local management strategies toward a more sustainable social and ecological development. Due to China's political and social heritage, regulatory mechanisms by legislation have been the government's preferred policy instrument (Xu 1999). Since the 1970s, a national environmental policy framework has been developed by adapting more than 30 environmental laws and regulations. The Law on Water Pollution Control (1984), the Environmental Protection Law (1989), the Soil and Water Conservation Law (1991), and the Water Law (2002) remain the most important national laws attempting to ensure an improvement of environmental quality and to establish sustainable development in China (Zhang and Wen 2008).

The main river basin authority, the Yellow River Conservancy Commission (YRCC), was established in 1929 as 
an institution for flood control and water resources development. The early management strategies were dominated by pure supply-driven and engineering-dominated approaches, but are now shifting toward more holistic and demand-based strategy not only linking social and economic development but also considering the conservation of natural ecosystems (Boxer 2001).

To address river desiccation and increasing water demand by a growing population and economy, and to manage water quantity in a more sustainable way in the basin, the State Council approved the Yellow River Water Allocation Scheme to manage water shortage and scarcity in 1987 (Cai 2008). This river basin regulatory tool allocates water withdrawal quota and permits to all riparian provinces and assigns the YRCC as responsible entity for implementation. It is worth noting that is this scheme also took environmental water requirements into consideration in order to maintain the ecosystem services in the lower reaches. However, flow-cut events did not disappear after implementation of the 1987 scheme; in fact, they even became worse. Provincial governments violated rules regularly due to a lack of monitoring capacity and the weakness in law enforcement of the YRCC. Further, provinces were able to institute their own laws, often detrimental to other provinces, causing heterogeneity in policy (Zhu et al. 2003; Xia and Pahl-Wostl 2012). Hence, the UWFR, implemented by the YRCC in 1999, addresses the main shortcomings of the 1987 scheme and improved the water allocation scheme substantially. The targets for monthly water releases for each major dam are calculated, based on current reservoir storage, weather forecast, and water demand (Ringler et al. 2010). To approach the lack of monitoring, the YRCC established provincial water bureaus that can better control water allocation and manage the operation of large reservoirs. The YRCC has been allocating water unifiedly to each of the provinces and regions. The enforcement of the UWFR has proven very successful in practice as the Yellow River has not ceased to flow since 1999. Later, the innovate New Water Law was adopted in 2002, the outcome of negotiations between state, river basin authorities, and provincial officials. It has strengthened the YRCC as a formal river basin authority, and the river basin commission was set above province level, with mandates to implement reforms and create regional river basin bureaus. Furthermore, it received more financial resources. The YRCC defined critical thresholds for water discharge and water abstractions are constrained or even stopped if water discharge falls below the critical value. The major problem of the current water management is the lack of financial compensation, so local users are often not willing to follow the rules.

Inspired by the theory of economic instruments, the Chinese government has recently also started to introduce economic and market-based instruments and is now shifting away from pure command and regulating instruments (Zhang and Wen 2008). As they internalize environmental costs associated with production and consumption, economic-based instruments, if they are well designed and implemented and should influence the behavior and decision-making of polluters and consumers, helping to meet policy goals. Common mechanisms include the use of pricing mechanisms (taxes, subsides, pollution charges, and payments for ecosystem services), tradable permits for pollutants or emissions, and investment incentives for greener technologies or environmental protection and restoration (Dinar et al. 1997; Starvins 2000). Despite many pricing reforms in the last years, however, the water itself is thought to be underpriced (Webber et al. 2008; Ringler et al. 2010). Increasing its price could influence the decision-making of water users toward higher water efficiency avoiding unsustainable water waste. Pricing usually works well for domestic and industrial users, but is very challenging for agricultural water users, as they are the dominant water user but only produce low-value products and have relatively low income (Ringler et al. 2010). Their livelihoods depend heavily on the use of water for irrigating their crops, and charging higher prices would result in a direct reduction in farmer's revenue, with significant social effects. Hence, it is a major task to find appropriate water prices for farmers to avoid adverse social consequences, such as impoverishment of the rural population, but at the same time to achieve gains in efficiency (Cai 2008). Besides pricing reforms, water-use rights and tradable permits could promote a more efficient water allocation, as they establish rights and responsibilities for users to allocate resources from low-value to high-value production. Although no formal water market has been established in the basin, in some upstream regions in Inner Mongolia, the YRCC experimented with local-level water rights transactions between power industry and agricultural irrigation districts (Xia and Pahl-Wostl 2012). The basic concept of this experiment was to stimulate agricultural water conservation infrastructure by the industrial sector, which received the conserved water quantity in return. This concept was later extended to other provinces.

In the last decade, the urgency of ecological restoration and conservation to restore ecosystem functions, carbon sequestration, hydrological services, and soil retention capacity, has become obvious for various stakeholder and the government fostered many policies and projects. The degraded Loess Plateau became target region for one of the largest restoration programs worldwide: the "Loess Plateau Watershed Rehabilitation Program" launched in 1996 (Fig. 8). Financed by the World Bank, this project targeted specifically degraded areas with low vegetation coverage and high erosion rates. The primary objectives include a 

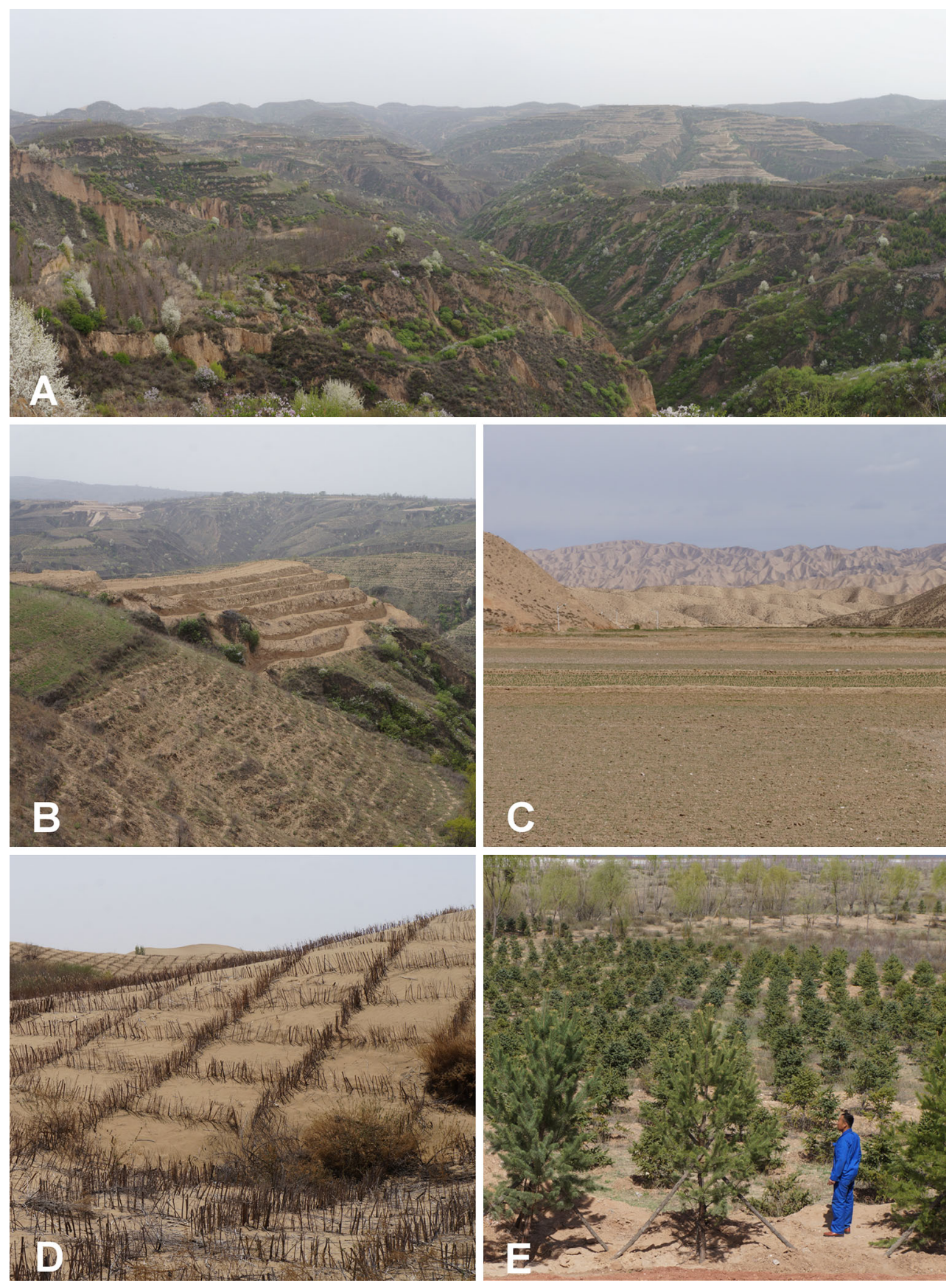

Fig. 8 Central Loess Plateau (a) in Shaanxi after the ecological restoration $\left(37^{\circ} 08^{\prime} 59^{\prime \prime} \mathrm{N}, 110^{\circ} 17^{\prime} 24^{\prime \prime} \mathrm{E}\right) ;$ b depicts newly created terraced fields for agricultural cultivation $\left(37^{\circ} 10^{\prime} 41^{\prime \prime} \mathrm{N}, 110^{\circ} 46^{\prime} 03^{\prime \prime} \mathrm{E}\right)$ and $\mathbf{c}$ shows degraded and sparsely vegetation areas Loess Plateau region in Gansu province not $\left(36^{\circ} 07^{\prime} 43^{\prime \prime} \mathrm{N}, 104^{\circ} 15^{\prime} 30^{\prime \prime} \mathrm{E}\right)$; Planted

square grass mats (d) in Inner Mongolia at the eastern edge of Gobi to prevent and reserve desertification process $\left(40^{\circ} 44^{\prime} 41^{\prime \prime} \mathrm{N}\right.$, $108^{\circ} 24^{\prime} 36^{\prime \prime} \mathrm{E}$ ). Pine nursery (e) in the valleys of the Loess Plateau for afforesting slopes $\left(37^{\circ} 11^{\prime} 55^{\prime \prime} \mathrm{N}, 110^{\circ} 49^{\prime} 58^{\prime \prime} \mathrm{E}\right.$ ) (photographs taken by Christian Wohlfart in April 2016)

more sustainable crop production on fertile soils on terraced gulch slopes and to stabilize the highly erosive soils by planting trees and shrubs to minimize the loss of valuable land to desertification. Besides the emphasis on ecological enhancement, this project aimed to support local farming structures and improve the living standards of local's toward a reduction in impoverishment of rural

locals. Following the international trend, the Chinese government started to implement a number of national and regional polices on payments for ecosystem services (PES) (Barnett et al. 2006; Zhen and Zhang 2011). Most of the PES programs are targeted to improve water quality and quantity, to control soil erosion, and to promote biodiversity. Two major programs are the aforementioned Natural 
Forest Conservation (NFC) program and the Grain for Green (GfG) program. The former aims to conserve natural forests in the upper reaches through logging restrictions and incentives of afforestation. Participating forest companies were compensated for their economic losses for allowing forest regeneration, and they also received payments for afforestation with native tree species. Since 2000 , the afforested area in the basin increased from 11,570 to $17,200 \mathrm{~km}^{2}$ (Xiang-zhou et al. 2004; Miao et al. 2010). The second major PES initiative, the GfG program, involves the direct compensation to individual farmers for converting cropland on steep slopes to forest or grassland, mainly in the Loess Plateau. Farmers were either provided with direct financial compensation or received grain as replacement for each hectare of cropland they converted. The total area subjected to the GfG initiative reached $82,700 \mathrm{~km}^{2}$ (1999-2006) and contributed to a significant increase in vegetation coverage by more than $10 \%$ since 1999 (Zhou et al. 2009; Miao et al. 2012; Zhai et al. 2015). Both programs can be considered successful implementations of PES schemes in China. However, the initially proposed period of 8 years of financing might not be enough to guarantee an effective ecosystem recover, as farmers tend to convert back to cropland if payments cease. Therefore, the Chinese government approved the extension to an additional 8 year cycle. Many scientific studies reveal changing and improving ecological conditions and show the successful recovery of grass- and woodland from barren and spare land (Chen et al. 2009; Miao et al. 2012; Liu et al. 2013a; Zhai et al. 2015).

Apart from these two policy instruments, various other tools exist, such as capacity training and education of local people to raise public awareness, self-regulation, consultation and negotiation, or community involvement (Bemelmans-Videc et al. 2003; Barnett et al. 2006). All these tools complement to each other well on different governing levels for achieving policy goals and promoting sustainable development in the basin. Given the size of the basin, no single measure could possibly solve all of the existing problems in the basin and a mix of well-integrated policy measures is required. It is also important to adapt these various policy instruments to the prevailing sociocultural circumstances. Another important issue is that policies should target social inequality in the basin in order to better integrate the concerns of rural people. So far, the benefits of growth have not necessarily touched the poorest.

Indeed, the YRCC started to establish regular meetings on various topics to bring all involved stakeholders together. In place since 2003, the biannual International Yellow River Forum is a large international conference and serves as an exchange and communication platform where governmental entities, scientific institutions, NGOs, and industry share their experience in river basin management to jointly develop management strategies for the Yellow River basin. This forum is the first step toward a better horizontal integration. Information sharing, data harmonization, science and technology support, and public participation should be prioritized and accomplished by a strong river basin commission.

\section{Conclusion}

The Yellow River is an illustrative example of a region with various, complex social-ecological challenges and the difficulties to manage such a dynamic and vulnerable river system to achieve long-term sustainable development. The major problems and challenges these days facing the basin result from long-term abuse of the basin's natural resources underpinned by policy choices, cultural attitude, and institutions that have evolved over centuries in China. In this study, we presented a comprehensive overview about the recent socioeconomic and environmental dynamics and major challenges pressing the social-ecological system of the basin.

The river has played a major role in the growth and prosperity of Chinese civilization and has been, and continues to be, one of the most dynamic and important regions in China. Today, the basin is impacted by rapid industrialization and population growth, urbanization, agricultural intensification and expansion, as well as climate change and a blueprint for current global change processes. However, this tremendous economic growth has been mainly achieved at the costs of the environment by extracting and developing natural resources in a rigorous, unsustainable manner. This development might not only offset economic benefits, but also threaten social stability. While flooding belongs historically to the river and has been the primary issue in river management for centuries, major achievements in flood control and mitigation have been made and are now largely under control. But new various environmental and social problems, including soil and water pollution, ecological degradation, water scarcity, and food security, further aggravated by climate change have risen.

To resolve these complex and multi-faceted challenges in the basin, a more holistic and integrated basin management is required and should incorporate all different needs and interests of all users. River basins are dynamic over space and time, and changes in any single component can influence the whole basin. Certainly, the aforementioned challenges are recognized by Chinese government and many individual environmental laws and regulation by several ministries have been enacted, but they usually pursue quite different and often contradictory goals. 
Further, these national regulations are quite general and often not applicable to specific problems. Therefore, localized management and a better vertical and horizontal policy coordination helps to ensure that these issues are better incorporated into policies specifically tailored to solve the particular problems faced. Instead of taking the strong traditional top-down approach, local people and nongovernmental bodies should be better integrated into the decision-making process. It is the task of a strong and proper designed river basin commission to coordinate all involved stakeholders and balance the different interests, with mutual benefits, also those of poorer locals, and should not be determined by political and provincial constrains. The main river basin authority-the YRCC-is now following a new management strategy toward a more integrated resources management to ensure social equity, economic efficiency, and ecological sustainability. An effective and integrated river basin management demands profound basin-wide data sets for retrieving information about biophysical, environmental, and socioeconomic circumstances necessary for strategic decision-making at the river basin scale. Despite the growing amount of data emanating from governmental institutions and national and international research, this information is often hard to access, fragmented, inconsistent, or outdated. The more integrated the river basin management is supposed to be, the more efforts need to be made regarding collaborative decision management, information sharing and interoperability of data. One way handling and sharing information could be the establishment of a common platform for spatial information in form of an inter- and transdisciplinary geographical information system (e.g., possibly operated by the YRCC), on which decision-making processes can be based on to manage sustainably water and land resources, as well as socioeconomic aspects, such as hydro-meteorological, water and quality data, and land use/cover characteristics. This information can be retrieved by either in situ monitoring, modelling techniques, or with remote sensing applications. The latter has the capability to monitor timely consistent dynamics on large scale to evaluate environmental conditions and to derive various thematic maps. In conjunction to remote sensing information, a well-developed set of various simulation models in hydro-meteorological or even socioeconomic context can further optimize and support planning and management strategies and scenarios for future development. Such systems have already been successfully implemented in other river basins globally, but always needs to be tailored to the respective requirements of the stakeholders in the Yellow River basin and serves as a medium for all kind information products, such as maps, reports, statistics, and recommended procedures. The initiated large-scale conservation and restoration programs in conjunction with international organizations ("Watershed Rehabilitation Program" or the "Grain-for-Green" Program) were first steps toward a more sustainable basin, also considering social facets against rural impoverishment. However, despite this ongoing success, management policies and reforms are still required and a promising solution is to adapt existing international knowledge in river basin management to the complex conditions in the basin. Also, more flexible economic incentives are powerful tools to influence decision-making within the basin to enable a more sustainable development. However, haste is needed, as the still ongoing rapid economic growth and the expected impacts of climate change in the basin, demands fast and effective institutional and policy reforms.

Acknowledgments This study was undertaken in the context of the DELIGHT Project (http://www.delight.eoc.dlr.de/), funded by the German Federal Ministry of Education and Research, BMBF, by the International Science \& Technology Cooperation Program of China, 2012DFG22050 and in cooperation with the Project RCEIS.

\section{References}

Barnett J, Webber M, Wang M et al (2006) Ten key questions about the management of water in the Yellow River basin. Environ Manag 38:179-188. doi:10.1007/s00267-005-0068-7

Bemelmans-Videc ML, Rist RC, Vedung EO (2003) Carrots, sticks, and sermons: policy instruments and their evaluation. Transaction Publishers, New Brunswick

Bi X, Wang B, Lu Q (2011) Fragmentation effects of oil wells and roads on the Yellow River Delta, North China. Ocean Coast Manag 54:256-264. doi:10.1016/j.ocecoaman.2010.12.005

Boxer B (2001) Contradictions and challenges in china's water policy development. Water Int 26:335-341. doi:10.1080/ 02508060108686925

Brakenridge GR (2016) Global active archive of large flood events. In: Dartmouth Flood Observatory, University of Colorado. http:// floodobservatory.colorado.edu/Archives/index.html. Accessed 10 Feb 2016

Cai X (2008) Water stress, water transfer and social equity in Northern China-implications for policy reforms. J Environ Manag 87:14-25. doi:10.1016/j.jenvman.2006.12.046

Cai X, Rosegrant MW (2004) Optional water development strategies for the Yellow River Basin: balancing agricultural and ecological water demands. Water Resour Res. doi:10.1029/ 2003WR002488

Casey RE, Klaine SJ (2001) Nutrient attenuation by a riparian wetland during natural and artificial runoff events. J Environ Qual 30:1721-1731

Chen J, He D, Cui S (2003) The response of river water quality and quantity to the development of irrigated agriculture in the last 4 decades in the Yellow River Basin. Water Resour Res, China. doi:10.1029/2001WR001234

Chen L, Wei W, Fu B, Lu Y (2007) Soil and water conservation on the Loess Plateau in China: review and perspective. Prog Phys Geogr 31:389-403. doi:10.1177/0309133307081290

Chen Y-F, Liu Y-S, Wang J et al (2009) Land use changes of an aeolian-loessial soil area in northwest China: implications for ecological restoration. Pedosphere 19:356-361. doi:10.1016/ S1002-0160(09)60126-0 
Chen Y, Syvitski JPM, Gao S et al (2012) Socio-economic impacts on flooding: a 4000-year history of the Yellow River, China. Ambio 41:682-698. doi:10.1007/s13280-012-0290-5

Cui X, Graf H-F (2009) Recent land cover changes on the Tibetan Plateau: a review. Clim Change 94:47-61. doi:10.1007/s10584009-9556-8

Cui B, Yang Q, Yang Z, Zhang K (2009) Evaluating the ecological performance of wetland restoration in the Yellow River Delta, China. Ecol Eng 35:1090-1103. doi:10.1016/j.ecoleng.2009.03. 022

Cui B, Zhang Q, Zhang K et al (2011) Analyzing trophic transfer of heavy metals for food webs in the newly-formed wetlands of the Yellow River Delta, China. Environ Pollut 159:1297-1306. doi:10.1016/j.envpol.2011.01.024

Deng X-P, Shan L, Zhang H, Turner NC (2006) Improving agricultural water use efficiency in arid and semiarid areas of China. Agric Water Manag 80:23-40. doi:10.1016/j.agwat.2005. 07.021

Dinar A, Rosegrant MW, Meinzen-Dick R (1997) Water allocation mechanisms: principles and examples. The World Bank, Washington, DC

Dong L, Wang W, Ma M et al (2009) The change of land cover and land use and its impact factors in upriver key regions of the Yellow River. Int J Remote Sens 30:1251-1265. doi:10.1080/ 01431160802468248

Economy EC (2010) The river runs black: the environmental challenge to China's future. Cornell University Press, Ithaka

Falkenmark M, Widstrand CG (1992) Population and water resources: a delicate balance. Population Reference Bureau, Washington, DC

Feng K, Siu YL, Guan D, Hubacek K (2012) Assessing regional virtual water flows and water footprints in the Yellow River Basin, China: a consumption based approach. Appl Geogr 32:691-701

Fu G, Chen S, Liu C, Shepard D (2004) Hydro-climatic trends of the Yellow River Basin for the last 50 years. Clim Change 65:149-178. doi:10.1023/B:CLIM.0000037491.95395.bb

Ghose B (2014) Food security and food self-sufficiency in China: from past to 2050. Food Energy Secur 3:86-95. doi:10.1002/ fes 3.48

Gilliam JW (1994) Riparian wetlands and water quality. J Environ Qual 65:896-900

Giordano M, Zhu Z, Cai X, et al (2004) Water management in the Yellow River Basin: background, current critical issues and future research needs. Comprehensive assessment research report 3, Colombo

Guobin L (1999) Soil conservation and sustainable agriculture on the Loess Plateau: challenges and prospects. Ambio 28:663-668

Gupta H, Kao S-J, Dai M (2012) The role of mega dams in reducing sediment fluxes: a case study of large Asian rivers. J Hydrol 464-465:447-458. doi:10.1016/j.jhydrol.2012.07.038

Hao F, Zhang X, Ouyang W et al (2012) Vegetation NDVI Linked to temperature and precipitation in the upper catchments of Yellow River. Environ Model Assess 17:389-398. doi:10.1007/s10666011-9297-8

Hijmans RJ, Cameron SE, Parra JL et al (2005) Very high resolution interpolated climate surfaces for global land areas. Int J Climatol 25:1965-1978. doi:10.1002/joc. 1276

Hu Y, Maskey S, Uhlenbrook S (2012) Trends in temperature and rainfall extremes in the Yellow River source region, China. Clim Change 110:403-429. doi:10.1007/s10584-011-0056-2

Huang S, Li J, Xu M et al (2007) Dynamic monitoring of Yellow River Estuary based on remote sensing in the recent ten years and analysis of correlation with flow and sediment condition. 2007 IEEE International Geoscience and Remote Sensing
Symposium, Barcelona, pp 5327-5330. doi:10.1109/IGARSS. 2007.4424065

Hui Y, Zheng M, Liu Z, Gao L (2009) Distribution of polycyclic aromatic hydrocarbons in sediments from Yellow River Estuary and Yangtze River Estuary, China. J Environ Sci 21:1625-1631. doi:10.1016/S1001-0742(08)62465-1

IPCC (2013) Climate change 2013 - the physical science basis: working group I contribution to the fifth assessment report of the IPCC. Cambridge University Press, Cambridge, New York

IUCN (2015) The IUCN red list of threatened species. Version 2015.2. http://www.iucnredlist.org. Accessed 10 Aug 2015

IUCN, UNEP-WCMC (2015) The World Database on Protected Areas (WDPA). www.protectedplanet.net. Accessed 10 Nov 2015

Jiang Y, Dong W, Yang S, Ma J (2008) Long-term changes in ice phenology of the Yellow River in the past decades. J Clim 21:4879-4886. doi:10.1175/2008JCLI1872.1

Ju X, Liu X, Zhang F, Roelcke M (2004) Nitrogen fertilization, soil nitrate accumulation, and policy recommendations in several agricultural regions of China. Ambio 33:300-305

Kuenzer C (2007) Water pollution, scarcity and distribution challenges. Bus Forum China, 02/07, 63-65

Kuenzer C, Campbell I, Roch M et al (2013) Understanding the impact of hydropower developments in the context of upstreamdownstream relations in the Mekong river basin. Sustain Sci 8:565-584. doi:10.1007/s11625-012-0195-z

Kuenzer C, Ottinger M, Liu G et al (2014) Earth observation-based coastal zone monitoring of the Yellow River Delta: dynamics in China's second largest oil producing region over four decades. Appl Geogr 55:92-107. doi:10.1016/j.apgeog.2014.08.015

Lawler A (2009) Beyond the Yellow River: how China became China. Science 325(80):930-935

Li G (2005) Maintaining the healthy life of the Yellow River. Yellow River Conservancy Press, Zhengzhou

Li G, Wei H, Han Y, Chen Y (1998a) Sedimentation in the Yellow River delta, part I: flow and suspended sediment structure in the upper distributary and the estuary. Mar Geol 149:93-111. doi:10. 1016/S0025-3227(98)00031-0

Li G, Wei H, Yue S et al (1998b) Sedimentation in the Yellow River delta, part II: suspended sediment dispersal and deposition on the subaqueous delta. Mar Geol 149:113-131. doi:10.1016/S00253227(98)00032-2

Li X, Cheng G, Jin H et al (2008) Cryospheric change in China. Glob Planet Change 62:210-218. doi:10.1016/j.gloplacha.2008.02.001

Li X, Brierley G, Shi D et al (2012) Ecological protection and restoration in Sanjiangyuan National Nature Reserve, Qinghai Province, China. In: Higgitt D (ed) Perspectives on environmental management and technology in Asian river basins. Springer, Dordrecht, pp 93-120

Liu C, Xia J (2004) Water problems and hydrological research in the Yellow River and the Huai and Hai River basins of China. Hydrol Process 18:2197-2210. doi:10.1002/hyp.5524

Liu L, Zhang B, Bi J (2012) Reforming China's multi-level environmental governance: lessons from the 11th Five-Year Plan. Environ Sci Policy 21:106-111. doi:10.1016/j.envsci.2012. 05.001

Liu J, Li Z, Zhang X et al (2013a) Responses of vegetation cover to the Grain for Green Program and their driving forces in the HeLong region of the middle reaches of the Yellow River. J Arid Land 5:511-520. doi:10.1007/s40333-013-0177-8

Liu Y, Huang H, Qiu Z, Fan J (2013b) Detecting coastline change from satellite images based on beach slope estimation in a tidal flat. Int J Appl Earth Obs Geoinf 23:165-176. doi:10.1016/j.jag. 2012.12.005 
Lohmar B, Wang J, Rozelle S et al (2003) China's Agricultural Water Policy Reforms. United States Department of Agriculture, Washington

Loucks CJ, Zhi L, Dinerstein E et al (2003) The giant pandas of the Qinling Mountains, China: a case study in designing conservation landscapes for elevational migrants. Conserv Biol 17:558-565. doi:10.1046/j.1523-1739.2003.01494.x

Ma Y, Huang HQ, Nanson GC et al (2012) Channel adjustments in response to the operation of large dams: the upper reach of the lower Yellow River. Geomorphology 147-148:35-48. doi:10. 1016/j.geomorph.2011.07.032

Miao C, Ni J, Borthwick AGL (2010) Recent changes of water discharge and sediment load in the Yellow River basin, China. Prog Phys Geogr 34:541-561. doi:10.1177/0309133310369434

Miao C, Ni J, Borthwick AGL, Yang L (2011) A preliminary estimate of human and natural contributions to the changes in water discharge and sediment load in the Yellow River. Glob Planet Change 76:196-205. doi:10.1016/j.gloplacha.2011.01.008

Miao CY, Yang L, Chen XH, Gao Y (2012) The vegetation cover dynamics (1982-2006) in different erosion regions of the Yellow River Basin, China. Land Degrad Dev 71:62-71

Milliman JD, Meade H (1983) World-wide delivery of river sediment to the oceans. J Geol 91:1-21

Nakaegawa T, Kitoh A, Hosaka M (2013) Discharge of major global rivers in the late 21 st century climate projected with the high horizontal resolution MRI-AGCMs. Hydrol Process 27:3301-3318. doi:10.1002/hyp.9831

Nakayama T (2011) Simulation of the effect of irrigation on the hydrologic cycle in the highly cultivated Yellow River Basin. Agric For Meteorol 151:314-327. doi:10.1016/j.agrformet.2010. 11.006

NBS (2015) China statistical database. http://www.stats.gov.cn. Accessed 21 Oct 2015

Ni J (2011) Impacts of climate change on Chinese ecosystems: key vulnerable regions and potential thresholds. Reg Environ Change 11:49-64. doi:10.1007/s10113-010-0170-0

Olson DM, Dinerstein E, Wikramanayake ED et al (2001) Terrestrial ecoregions of the world: a new map of life on earth. Bioscience 51:933-938

Ottinger M, Kuenzer C, Liu G et al (2013) Monitoring land cover dynamics in the Yellow River Delta from 1995 to 2010 based on Landsat 5 TM. Appl Geogr 44:53-68

Ottinger M, Clauss K, Kuenzer C (2016) Aquaculture: relevance, distribution, impacts and spatial assessments-a review. Ocean Coast Manag 119:244-266. doi:10.1016/j.ocecoaman.2015.10. 015

Ouyang W, Hao FH, Zhao C, Lin C (2010) Vegetation response to 30 years hydropower cascade exploitation in upper stream of Yellow River. Commun Nonlinear Sci Numer Simul 15:1928-1941. doi:10.1016/j.cnsns.2009.07.021

Peng J, Chen S, Dong P (2010) Temporal variation of sediment load in the Yellow River basin, China, and its impacts on the lower reaches and the river delta. Catena 83:135-147. doi:10.1016/j. catena.2010.08.006

Piao S, Ciais P, Huang Y et al (2010) The impact of climate change on water resources and agriculture in China. Nature 467:43-51

Qi S, Fang L (2007) Environmental degradation in the Yellow River Delta, Shandong province, China. Ambio 36:610-611. doi:10. 1579/0044-7447(2007)36[610:EDITYR]2.0.CO;2

Ran L, Lu XX (2012) Delineation of reservoirs using remote sensing and their storage estimate: an example of the Yellow River basin, China. Hydrol Process 26:1215-1229. doi:10.1002/hyp. 8224

Ringler C, Cai X, Wang J et al (2010) Yellow River basin: living with scarcity. Water Int 35:681-701. doi:10.1080/02508060.2010. 509857
Shi H, Shao M (2000) Soil and water loss from the Loess Plateau in China. J Arid Environ 45:9-20. doi:10.1006/jare.1999.0618

Starvins RN (2000) Market based environmental policies. In: Portney PN, Stavins RN (eds) Public policies for environmental protection. Resources of the Future, Washington, DC, pp 31-77

Syvitski JPM, Kettner AJ, Overeem I et al (2009) Sinking deltas due to human activities. Nat Geosci 2:681-686

Tang Q, Oki T, Kanae S, Hu H (2008) A spatial analysis of hydroclimatic and vegetation condition trends in the Yellow River basin. Hydrol Process 458:451-458. doi:10.1002/hyp

Tao F, Zhang Z (2013) Climate change, wheat productivity and water use in the North China Plain: a new super-ensemble-based probabilistic projection. Agric For Meteorol 170:146-165. doi:10.1016/j.agrformet.2011.10.003

Tao F, Hayashi Y, Zhang Z et al (2008) Global warming, rice production, and water use in China: developing a probabilistic assessment. Agric For Meteorol 148:94-110. doi:10.1016/j. agrformet.2007.09.012

Tisdell C (2009) Economic reforms and openness in China: Chinás policies in the last 30 years. Econ Anal Policy 39:271-294

UNDP (1999) China human development report 1999: transition and the state. Oxford University Press, New York

Wang H, Yang Z, Saito Y et al (2006) Interannual and seasonal variation of the Huanghe (Yellow River) water discharge over the past 50 years: connections to impacts from ENSO events and dams. Glob Planet Change 50:212-225. doi:10.1016/j.gloplacha. 2006.01.005

Wang H, Yang Z, Saito Y et al (2007) Stepwise decreases of the Huanghe (Yellow River) sediment load (1950-2005): impacts of climate change and human activities. Glob Planet Change 57:331-354. doi:10.1016/j.gloplacha.2007.01.003

Wang S, Ding C, Liu J (2009) Landscape evolution in the Yellow River Basin using satellite remote sensing and GIS during the past decade. Int J Remote Sens 30:5573-5591. doi:10.1080/ 01431160802687482

Wang H, Bi N, Saito Y et al (2010) Recent changes in sediment delivery by the Huanghe (Yellow River) to the sea: causes and environmental implications in its estuary. J Hydrol 391:302-313. doi:10.1016/j.jhydrol.2010.07.030

Wang X, Yu J, Zhou D et al (2012) Vegetative ecological characteristics of restored reed (Phragmites australis) wetlands in the Yellow River Delta, China. Environ Manag 49:325-333. doi:10.1007/s00267-011-9757-6

Wang H, Gao J, Ren L-L et al (2013) Assessment of the red-crowned crane habitat in the Yellow River Delta Nature Reserve, East China. Reg Environ Change 13:115-123. doi:10.1007/s10113012-0325-2

Webber M, Barnett J, Wang M et al (2008) The Yellow River in transition. Environ Sci Policy 11:422-429. doi:10.1016/j.envsci. 2008.02.002

Wei J, Zhou J, Tian J et al (2006) Decoupling soil erosion and human activities on the Chinese Loess Plateau in the 20th century. CATENA 68:10-15. doi:10.1016/j.catena.2006.04.011

Wen D, Zhang F, Zhang E et al (2009) Outline of the Yellow River basin, China. Bull Geol Surv Jpn 60:9-18

Wu B, Wang Z, Li C (2004) Yellow River Basin management and current issues. J Geogr Sci 14:29-37. doi:10.1007/BF02841104

Wu CS, Yang SL, Lei Y (2012) Quantifying the anthropogenic and climatic impacts on water discharge and sediment load in the Pearl River (Zhujiang), China (1954-2009). J Hydrol 452-453:190-204. doi:10.1016/j.jhydrol.2012.05.064

Wu Q, Hou Y, Yun H, Liu Y (2015) Changes in active-layer thickness and near-surface permafrost between 2002 and 2012 in alpine ecosystems, Qinghai-Xizang (Tibet) Plateau, China. Glob Planet Change 124:149-155. doi:10.1016/j.gloplacha.2014.09.002 
Xia C, Pahl-Wostl C (2012) The development of water allocation management in The Yellow River Basin. Water Resour Manag 26:3395-3414. doi:10.1007/s11269-012-0078-1

Xia X, Zhou J, Yang Z (2002) Nitrogen contamination in the Yellow River Basin of China. J Environ Qual. doi:10.2134/jeq2002.9170

Xiang-zhou X, Hong-wu Z, Ouyang Z (2004) Development of checkdam systems in gullies on the Loess Plateau, China. Environ Sci Policy 7:79-86. doi:10.1016/j.envsci.2003.12.002

Xu H (1999) Environmental policy and rural industrial development in China. Res Hum Ecol 6:72-80

Xu J (2002a) River sedimentation and channel adjustment of the lower Yellow River as influenced by low discharges and seasonal channel dry-ups. Geomorphology 43:151-164. doi:10. 1016/S0169-555X(01)00131-3

$\mathrm{Xu} \mathrm{J} \mathrm{(2002b)} \mathrm{Implication} \mathrm{of} \mathrm{relationships} \mathrm{among} \mathrm{suspended} \mathrm{sediment}$ size, water discharge and suspended sediment concentration: the Yellow River basin, China. CATENA 49:289-307. doi:10.1016/ S0341-8162(02)00064-4

Xu J, Cheng D (2002) Relation between the erosion and sedimentation zones in the Yellow River, China. Geomorphology 48:365-382. doi:10.1016/S0169-555X(02)00145-9

$\mathrm{Xu} \mathrm{X}$, Lin H, Fu Z (2004) Probe into the method of regional ecological risk assessment-a case study of wetland in the Yellow River Delta in China. J Environ Manag 70:253-262. doi:10.1016/j.jenvman.2003.12.001

Xu J, Zhang Z, Liu W, McGowan PJK (2012) A review and assessment of nature reserve policy in China: advances, challenges and opportunities. Oryx 46:554-562

Yang D, Ishidaira H (2010) Profile of the Yellow River Basin. In: Kusuda $\mathrm{T}$ (ed) The Yellow River-water and life. World Scientific Publishing, Singapore, pp 5-24

Yang D, Li C, Hu H et al (2004a) Analysis of water resources variability in the Yellow River of China during the last half century using historical data. Water Resour Res. doi:10.1029/ 2003WR002763

Yang M, Wang S, Yao T et al (2004b) Desertification and its relationship with permafrost degradation in Qinghai-Xizang (Tibet) plateau. Cold Reg Sci Technol 39:47-53. doi:10.1016/j. coldregions.2004.01.002

Yang T, Zhang Q, Chen YD et al (2008) A spatial assessment of hydrologic alteration caused by dam construction in the middle and lower Yellow River, China. Hydrol Process 3843:3829-3843. doi:10.1002/hyp

YRCC (2013) Yellow River water resources bulletins. http://www. yrcc.gov.cn. Accessed 14 Nov 2015

Yu L (2002) The Huanghe (Yellow) River: a review of its development, characteristics, and future management issues. Cont Shelf Res 22:389-403. doi:10.1016/S0278-4343(01)00088-7
Yu L (2006) The Huanghe (Yellow) River: recent changes and its countermeasures. Cont Shelf Res 26:2281-2298

Yue TX, Liu JY, Jørgensen SE, Ye QH (2003) Landscape change detection of the newly created wetland in Yellow River Delta. Ecol Model 164:21-31. doi:10.1016/S0304-3800(02)00391-5

Zhai J, Liu R, Liu J et al (2015) Human-induced landcover changes drive a diminution of land surface albedo in the Loess Plateau (China). Remote Sens 7:2926-2941

Zhang K, Wen Z (2008) Review and challenges of policies of environmental protection and sustainable development in China. J Environ Manag 88:1249-1261. doi:10.1016/j.jenvman.2007. 06.019

Zhang J, Huang WW, Shi MC (1990) Huanghe (Yellow River) and its estuary: sediment origin, transport and deposition. J Hydrol 120:203-223. doi:10.1016/0022-1694(90)90150-V

Zhang Q, Xu C, Becker S, Jiang T (2006) Sediment and runoff changes in the Yangtze River basin during past 50 years. J Hydrol 331:511-523. doi:10.1016/j.jhydrol.2006.05.036

Zhang X, Wang M, Liang X (2009) Quantitative classification and carbon density of the forest vegetation in Lüliang Mountains of China BT. In: Valk AG (ed) Forest ecology: recent advances in plant ecology. Springer, Dordrecht, pp 1-9

Zhao D, Kuenzer C, Fu C, Wagner W (2008) Evaluation of the ERS scatterometer-derived soil water index to monitor water availability and precipitation distribution at three different scales in China. J Hydrometeorol 9:549-562. doi:10.1175/2007JHM965.1

Zhao T, Xu H, He Y et al (2009) Agricultural non-point nitrogen pollution control function of different vegetation types in riparian wetlands: a case study in the Yellow River wetland in China. J Environ Sci 21:933-939

Zhao T, Richards KS, Xu H, Meng H (2012) Interactions between dam-regulated river flow and riparian groundwater: a case study from the Yellow River, China. Hydrol Process 26:1552-1560. doi:10.1002/hyp.8260

Zhen L, Zhang H (2011) Payment for ecosystem services in China: an overview

Zhou H, Van Rompaey A, Wang J (2009) Detecting the impact of the "Grain for Green" program on the mean annual vegetation cover in the Shaanxi province, China using SPOT-VGT NDVI data. Land Use Policy 26:954-960. doi:10.1016/j.landusepol.2008.11. 006

Zhu Z, Cai X, Giordano M, et al (2003) Yellow River comprehensive assessment: basin features and issues. Colombo

Zhu Z, Giordano M, Cai X, Molden D (2004) The Yellow River Basin: water accounting, water accounts, and current issues. Water Int 29:2-10. doi:10.1080/02508060408691742 